\title{
Review \\ Strategies for Post-Translational Control of Protein Expression and Their Applications
}

\author{
Yuki Utsugi ${ }^{1}$ and Yusaku Miyamae ${ }^{2,3, *(1)}$ \\ 1 Master's/Doctoral Program in Life Science Innovation, Degree Programs in Comprehensive Human Sciences, \\ Graduate School of Comprehensive Human Sciences, University of Tsukuba, 1-1-1, Tennodai, \\ Tsukuba 305-8572, Ibaraki, Japan; utsugi.yuki.sp@alumni.tsukuba.ac.jp \\ 2 Faculty of Life and Environmental Sciences, University of Tsukuba, 1-1-1, Tennodai, \\ Tsukuba 305-8572, Ibaraki, Japan \\ 3 Alliance for Research on the Mediterranean and North Africa, University of Tsukuba, 1-1-1, Tennodai, \\ Tsukuba 305-8572, Ibaraki, Japan \\ * Correspondence: miyamae.yusaku.fw@u.tsukuba.ac.jp
}

Citation: Utsugi, Y.; Miyamae, Y Strategies for Post-Translational Control of Protein Expression and Their Applications. Appl. Sci. 2021, 11, 8300. https://doi.org/10.3390/ app11188300

Academic Editor: Giuseppina Andreotti

Received: 30 July 2021

Accepted: 2 September 2021

Published: 7 September 2021

Publisher's Note: MDPI stays neutral with regard to jurisdictional claims in published maps and institutional affiliations.

Copyright: (c) 2021 by the authors. Licensee MDPI, Basel, Switzerland. This article is an open access article distributed under the terms and conditions of the Creative Commons Attribution (CC BY) license (https:// creativecommons.org/licenses/by/ $4.0 /)$.

\begin{abstract}
Proteins are fundamental biomolecules of living cells, and their expression levels depend on the balance between the synthesis and degradation. Researchers often aim to control protein expression levels for the investigation of protein function and its relationship with physiological phenomena. The genetic manipulation of the target protein using CRISPR/Cas9, Cre/loxP, tetracyclin system, and RNA interference, are widely used for the regulation of proteins at the DNA, transcriptional, or mRNA level. However, the significant time delay in controlling protein levels is a limitation of these techniques; the knockout or knockdown effects cannot be observed until the previously transcribed and synthesized protein is degraded. Recently, researchers have developed various types of molecular tools for the regulation of protein expression at the post-translational level, which rely on harnessing cellular proteolytic machinery including ubiquitin-proteasome pathway, autophagylysosome pathway, and endocytosis. The post-translational control of protein expression using small molecules, antibodies, and light can offer significant advantages regarding speed, tunability, and reversibility. These technologies are expected to be applied to pharmacotherapy and cell therapy, as well as research tools for fundamental biological studies. Here, we review the established and recently developed technologies, provide an update on their applications, and anticipate potential future directions.
\end{abstract}

Keywords: targeted protein degradation; protein knockdown; chemical knockdown; degron; conditional knockdown

\section{Introduction}

The manipulation of cellular functions is one of the major approaches in biological research and is supported by the control of biomolecules, including DNA, RNA, proteins, peptides, and bioactive small molecules. In particular, researchers often aim to control the activity of specific proteins in mammalian cells, to understand phenomena of interest. The observation of the cellular output and phenotypes in cases of selective enhancement or perturbation of the activity of the target protein enables the deduction of its function. For this purpose, a variety of methods [1] are now available that allow the manipulation of the cellular abundance, localization, conformational change, enzymatic activity, and posttranslational modification of proteins, as well as their interaction with partners. Among them, controlling protein abundance is a robust approach compared with other methods because it directly ensures activity in cells.

Altering the gene or transcript encoding the target protein is broadly used for the regulation of cellular protein abundance. The CRISPR/Cas9 system, which is one of the representative approaches in this setting, uses a Cas9 endonuclease and a single-guide 
RNA (sgRNA) with a complementary sequence to the target DNA [2-4]. The sgRNA guides the Cas9 to the target site in the genome, for cleavage. The CRISPR/Cas9 system allows for the precise and efficient deletion or insertion of the target DNA. The Cre/loxP system is another classical technique that also controls protein expression at the DNA level [5-7]. Cre recombinase specifically excises a DNA sequence flanked by two loxP sites. The Cre/loxP system allows the excision from the genome of a target DNA flanked by the loxP sites by expressing Cre proteins in a target tissue and at the desired time. Although the techniques of genetic depletion have greatly contributed to the advancement of biological studies, some concerns remain: first, it is not easy to apply them to the regulation of core-essential genes, which are indispensable for the viability of mammalian cells [8,9]. Second, the living organism might adapt to the circumstances generated by the genetic depletion [10], which may mislead the interpretation of the phenotypic observations. Rather than controlling the target molecule at the DNA level, alternative approaches rely on the modulation of the gene of interest at the transcriptional level. The tetracycline (tet) system is a well-known tool for the transcriptional control of target protein expression that can be turned on or off using tet or its derivative, doxycycline (Dox) [11-13]. The tet system uses a fusion protein of the tetracycline ligand-binding domain to a sequence-specific transcription activation domain and a construct that contains a target gene under the control of a minimal promoter sequence combined with tet operator sequences. Another example of transcriptional control is the knockdown method based on RNA interference (RNAi), which is a regulatory mechanism present in most eukaryotic cells. RNAi uses small double-stranded RNA (dsRNA) molecules to direct homology-dependent degradation of the target mRNA $[14,15]$. Although these techniques have been widely used as gold standards for the modulation of target proteins, these approaches face a fundamental limitation, i.e., waiting for the natural clearance of the target proteins from the cell [16]. In the past few decades, researchers have developed technologies that regulate protein expression at the post-translational level. Those technologies enable the fast clearance or stabilization of the target protein, because the stability of the target protein is controlled directly. Most technologies used for post-translational control of protein expression take advantage of cellular proteolytic pathways.

Eukaryotic cells have two major proteolytic pathways: the ubiquitin-proteasome pathway [17] and the lysosomal pathway [18]. Many techniques used for the post-translational control of protein expression rely on the ubiquitin-proteasome pathway, which achieves selective proteolysis. Proteolytic substrates are modified with ubiquitin (Ub), a highly conserved 76-amino-acid polypeptide, which is conjugated to an internal lysine of the substrate through an isopeptide bond to the C-terminal glycine of $\mathrm{Ub}$. This reaction is generally called ubiquitination and occurs sequentially through the three steps with activating (E1), conjugating (E2), and ligase (E3) enzymes (Figure 1a). Ub is initially activated in an ATP-consuming reaction by an E1 enzyme, to which $\mathrm{Ub}$ is conjugated by a high-energy thioester bond. Subsequently, the activated $\mathrm{Ub}$ is transferred to a cysteine residue of an E2 enzyme, which then catalyzes the transfer of (poly) $\mathrm{Ub}$ to the substrate bound to an E3 enzyme. There are two major classes of E3 enzymes, characterized by Really Interesting New Gene (RING) and Homologous to E6-AP Carboxy Terminus (HECT) domains. RING E3 enzymes serve as a hub for the assembly of the E2 enzyme and the substrate, and catalyze the transfer of $\mathrm{Ub}$ directly from the E2 enzyme to the substrate. In contrast, HECT E3 enzymes have a distinct function of Ub transfer. The thioester moiety of the complex of activated $\mathrm{Ub}$ and the E2 enzyme is reacted with a cysteine residue in the HECT domain of the E3 enzyme, and is finally transferred to the substrate. Seven lysine residues of $\mathrm{Ub}(\mathrm{K} 6, \mathrm{~K} 11, \mathrm{~K} 27, \mathrm{~K} 29, \mathrm{~K} 33, \mathrm{~K} 48$, and $\mathrm{K} 63)$ allow the generation of $\mathrm{Ub}$ chains via an isopeptide bond between a lysine of one $\mathrm{Ub}$ and the $\mathrm{C}$-terminal glycine of another $\mathrm{Ub}$. The ubiquitinated substrate binds to internal $\mathrm{Ub}$ receptors in the $19 \mathrm{~S}$ regulatory complex of the $26 \mathrm{~S}$ proteasome, which is a multicatalytic protease. The substrate protein bound to the proteasome is unfolded by ATPases and the polyubiquitin chain is removed from the substrate by proteasome-associated deubiquitinating enzymes (DUBs) [19]. The unfolded 
protein is translocated into the central proteolytic chamber of 20S proteasome, where it is cleaved into short peptides. Certain types of DUBs are resident in the cytosol and act in the removal of the (poly)ubiquitin from substrates, which stabilizes the protein.

(a) ubiquitin-proteasome pathway

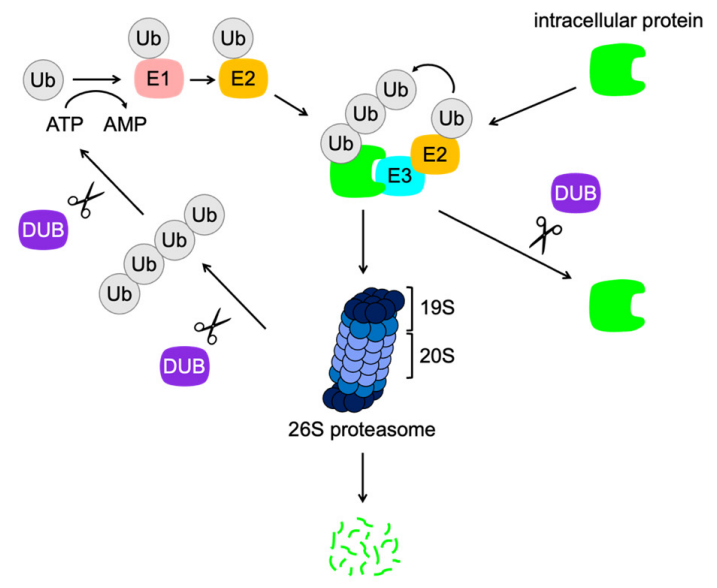

(b) autophagy-lysosomal pathway

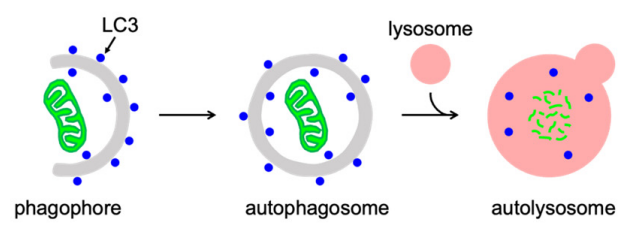

(c) endo-lysosomal pathway

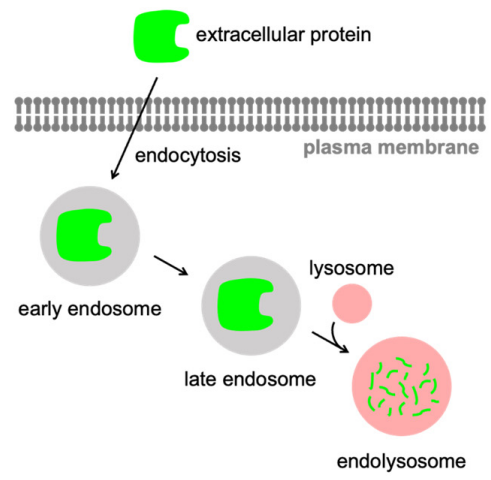

Figure 1. Cellular proteolytic pathways. Eukaryotic cells have several protein degradation pathways: (a) the ubiquitin-proteasome pathway, (b) the autophagy-lysosomal pathway, and (c) the endolysosomal pathway.

In contrast to the ubiquitin-proteasome pathway, the autophagy-lysosome pathway is capable of targeting not only proteins, but also cellular organelles [20]. The substrates are enclosed by an isolation membrane (called phagophore) which associate with the microtubule-associated protein light chain 3 (LC3) on their surface (Figure 1b). After its subsequent maturation and closure, the autophagosome is formed. The outer membrane of the autophagosome fuses with the lysosome, and the internal materials are degraded in the autolysosome. Although these processes are called "bulk" degradation system, autophagy mediates the selective degradation of substrate proteins and/or organelles through autophagy receptors, such as p62. These receptor proteins contain the LC3interacting region, which mediates their binding to nascent autophagosomes. The receptors 
also recognize the ubiquitinated substrates through an ubiquitin-binding domain and recruit them to the autophagosome, resulting in selective degradation by the lysosomes. Furthermore, there is another kind of degradation machinery of lysosomes that can target extracellular and plasma membrane proteins via endocytosis (Figure 1c). After endocytosis, internalized extracellular and plasma membrane proteins enter the early endosome. The early endosome matures into the late endosome, which then fuses with the lysosome to form an endolysosome, within which the internal materials are degraded.

The proteolytic pathways mentioned above have been utilized for various types of technologies of post-translational control of cellular protein expression. These technologies enable the regulation of the targeted protein in a rapid, reversible, and specific manner. In addition to harnessing the cellular proteolytic pathway, the usability of these technologies is supported by the uses of molecular switches, such as small molecules, antibodies, light irradiation, and their combinations. Small-molecule-based technologies provide rapid, tunable, and easy-to-use methodologies, and have been extensively developed. The use of an antibody may ensure specific control of the target protein rather than small molecules. Light irradiation achieves the spatiotemporal regulation of the target, which may be beneficial for application in vivo. The technologies used for the post-translational control of protein expression are mainly classified into two types: (1) targeted protein degradation using bifunctional molecules or antibodies and (2) conditional control of protein stability using genetic manipulation. There is growing interest in the development of further new methodologies and in their applications to the fields of fundamental biology and therapeutics. In this article, we review both established and recently developed technologies, provide an update on their applications, and anticipate potential future directions.

\section{Methodology}

To review the latest information on post-translational regulation of protein expression, we conducted in-depth search on PubMed and Google Scholar using the keywords "targeted protein degradation", "protein knockdown", "chemical knockdown", "degron", and "conditional knockdown". To gather further information on the techniques specific to each proteolytic pathway, the keywords related to intracellular pathways "ubiquitinproteasome", "autophagy", and "lysosome" were also used for the search. Those words were combined with the keywords of molecular switches "small molecule", "molecular glue", "light irradiation", "antibody", and "nanobody". To obtain additional information on the therapeutic applications of the technologies, we performed a further search using a combination of keywords "protein knockdown", "degron", "Drug Discovery", and "therapy". The information obtained for each class of technologies was carefully evaluated and summarized in tabular forms and then discussed to explain their concepts and mechanisms for their regulation, as well as their applications.

\section{Targeted Protein Degradation Using Bifunctional Molecules or Antibodies}

The representative strategies for post-translational control of protein expression are based on the use of bifunctional molecules. Those molecules enable the recruitment of a protein of interest (POI) to the molecular components of the proteolytic pathways, resulting in the selective degradation of POI. Antibodies-based approaches have also been developed. The technologies discussed below are summarized in Table 1.

\subsection{PROTAC}

A pioneering work on the targeted protein degradation is the recruitment of the target protein to specific E3 $\mathrm{Ub}$ ligases using bifunctional molecules. As a proof-of-concept, the Crews group developed a proteolysis-targeting chimeric molecule (PROTAC) consisting of specific ligands for a protein of interest (POI) and an E3 Ub ligase, with a linker connecting them (Figure 2a) [21]. PROTAC binds to both the POI and an E3 Ub ligase, resulting in the ubiquitination, and degradation of the POI. Those authors synthesized a chimeric large molecule called Protac-1 that recruits an E3 Ub ligase complex, Skp1-Cullin- 
F-box (SCF), to a target protein, methionine aminopeptidase-2 (MetAP-2), resulting in its ubiquitination, and degradation. They further developed an all-small-molecule and cellpermeable PROTAC that consists of a ligand for the non-steroidal androgen receptor and a ligand for the E3 Ub ligase MDM2, connected by a polyethylene glycol (PEG)-based linker (Figure 2a) [22]. Itoh et al. developed another chimeric molecule called specific and nongenetic IAP-dependent protein eraser (SNIPER), which recruits inhibitor of the apoptosis protein (IAP) Ub ligases to specifically degrade target proteins [23].

(a) proteolysis-targeting chimaera (PROTAC)/ specific and nongenetic IAP-dependent protein eraser (SNIPER)
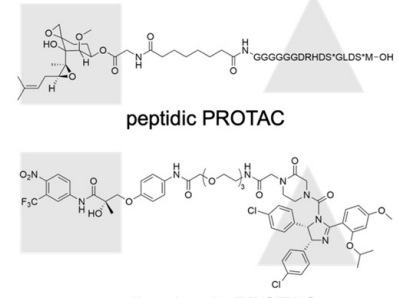

small molecule PROTAC

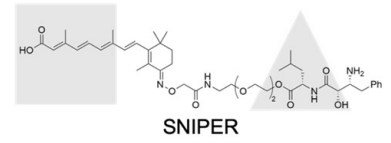

SNIPER

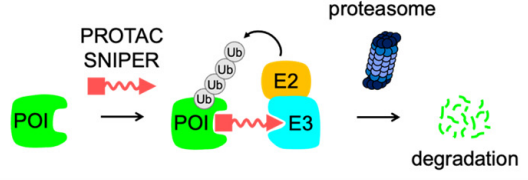

(b) TRIM-away

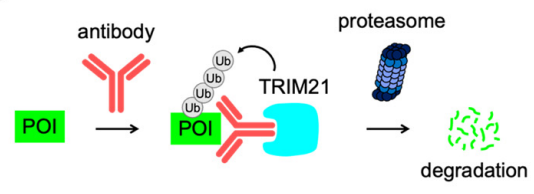

(c) autophagy-targeting chimera (AUTAC)

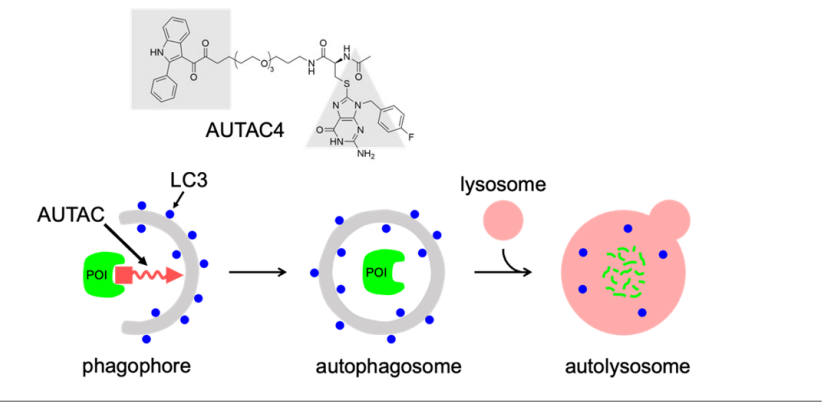

(d) lysosome-targeting chimaera (LYTAC)

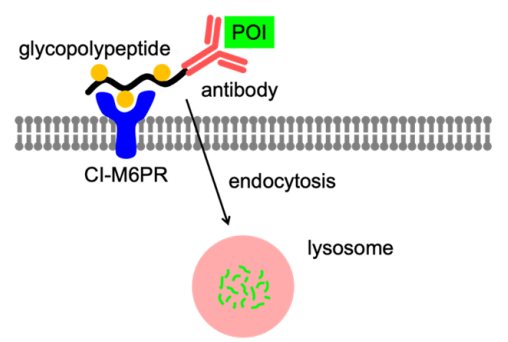

Figure 2. Targeted protein degradation using molecules or antibodies. Concepts of (a) PROTAC/SNIPER, (b) TRIM-away, (c) AUTAC, and (d) LYTAC. 
Such chimeric molecules require significant linker optimization and have a high molecular weight of 900-1100 Da, which limits cellular permeability and solubility. Kihlberg's group reported solution conformations of a von Hippel-Lindau (VHL) E3 Ub ligaserecruiting PROTAC that has a flexible, PEG-based linker [24]. This molecule exhibits an elongated conformation in a polar environment while the conformation is folded in an apolar environment. The folded conformation minimizes the size and polarity, allowing it to permeate the cell membrane. Furthermore, a new approach to solve the problem regarding molecular weight of PROTACs has also emerged. Lebraud et al. addressed this by using the bio-orthogonal reaction between two smaller precursors of chimeric molecule, which can occur intracellularly [25]. They designed a tetrazine-tagged ligand for an E3 Ub ligase that reacts rapidly with a trans-cyclo-octene-tagged ligand for POI in cells, to form an $\mathrm{E} 3 \mathrm{Ub}$ ligase and recruit PROTAC molecule: termed click-formed proteolysis targeting chimera (CLIPTAC). Recent studies achieved another important improvement of PROTAC using optochemistry technologies. Liu et al. developed a light-inducible switch on PROTACs, termed opto-PROTAC by decorating the ligand moiety for E3 ligase with a photolabile caging group [26]. This caged compound shows no activity in the dark, whereas restricted degradation can be induced at a specific time and rate after uncaging of photolabile group by light irradiation. Reynders et al. also developed photochemically targeting chimeras (PHOTACs) by introducing azobenzene moieties between ligands for the E3 Ub ligase and the POI [27]. Light irradiation causes the photoreversible isomerization of the azobenzene moiety and switches the active state to induce protein degradation activity. These technologies are useful for application in clinical settings because the spatiotemporal regulation afforded by them avoids the uncontrolled degradation that causes systemic toxicity.

Table 1. Comparison of the bifunctional molecule-based technologies.

\begin{tabular}{|c|c|c|c|}
\hline Technology & Proteolytic Pathway & Feature & References \\
\hline PROTAC/SNIPER & Ubiquitin-proteasome pathway & Originally developed bifunctional molecules & [21-23] \\
\hline CLIPTAC & Ubiquitin-proteasome pathway & $\begin{array}{l}\text { In-cell generation of bifunctional molecule by } \\
\text { the biorthogonal reaction }\end{array}$ & [25] \\
\hline opto-PROTAC & Ubiquitin-proteasome pathway & $\begin{array}{c}\text { Light-inducible switch on PROTAC by } \\
\text { photolabile caging group }\end{array}$ & [26] \\
\hline PHOTAC & Ubiquitin-proteasome pathway & $\begin{array}{l}\text { Light-inducible switch on PROTAC by } \\
\text { photo-reversible isomerization of } \\
\text { azobenzene moiety }\end{array}$ & [27] \\
\hline AbTAC & Ubiquitin-proteasome pathway & Capable of degrading the cell-surface protein & [28] \\
\hline Antibody-PROTAC conjugate & Ubiquitin-proteasome pathway & Cell-type selective targeting & [29] \\
\hline TRIM away & Ubiquitin-proteasome pathway & $\begin{array}{l}\text { Selective degradation of post-translational } \\
\text { modified protein and mutant variants }\end{array}$ & {$[30,31]$} \\
\hline AUTAC & Autophagy-lysosome pathway & Capable of targeting cellular organelles & {$[32]$} \\
\hline ATTEC & Autophagy-lysosome pathway & $\begin{array}{l}\text { Molecular glue type degrader for targeting } \\
\text { abnormal proteins }\end{array}$ & {$[33,34]$} \\
\hline LYTAC & Endocytosis & $\begin{array}{l}\text { Capable of targeting extracellular and } \\
\text { membrane-bound protein }\end{array}$ & {$[35,36]$} \\
\hline
\end{tabular}

\subsection{Antibody-Based Approaches}

Not only small molecules, but also antibodies are applicable to this type of strategy. Cotton et al. developed antibody-based PROTACs (AbTACs), which facilitates the recruitment of membrane-bound $\mathrm{E} 3 \mathrm{Ub}$ ligases to the targeted cell-surface protein, such as the programmed death-ligand 1 (PD-L1) [28]. Maneiro et al. proposed a different approach by conjugating the PROTAC molecule with an antibody against the human epidermal receptor 2 (HER2), to selectively target HER2-positive cells [29]. Once the antibody is recognized by HER2 on the cell-surface, the antibody-PROTAC conjugates are delivered to the cytosol 
by endosomal internalization. Subsequently, the released PROTAC molecules degrade the cellular target. Another antibody-based approach for targeted protein degradation was reported by Clift et al. They focused on TRIM21, which was originally found to act as an E3 $\mathrm{Ub}$ ligase in the immune response to pathogen infection. TRIM21 recognizes antibody-bound pathogens through a high-affinity interaction with the $\mathrm{Fc}_{\mathrm{c}}$ domain of the antibody and tags the antibody-bound pathogens for ubiquitination and degradation. Clift et al. repurposed TRIM21 to establish a method called Trim-Away that targets endogenous proteins for proteasomal degradation using endogenous or exogenous TRIM21 and antibodies that bind to the POI (Figure 2b) [30,31]. Notably, this technique enables the selective degradation of post-translationally modified protein and splice or mutant protein variants, by using a specific antibody, while preserving the unmodified/wild-type protein.

\subsection{Autophagy/Lysosome-Based Approaches}

Recently, several groups reported alternative approaches using proteolytic machinery including the autophagy-lysosome pathway, which is capable of targeting not only proteins, but also organelles. Arimoto and coworkers found that $S$-guanylation targets substrates for K63-linked polyubiquitination and selective autophagy [32]. They developed autophagytargeting chimeras (AUTACs) consisting of guanine derivatives that mimic the function of endogenous protein S-guanylation and a specific ligand for a POI (Figure 2c). AUTAC targets the POI for selective autophagy, and mitochondria-targeted AUTAC allows the removal of dysfunctional fragmented mitochondria via mitophagy. In contrast, Lu and colleagues developed a distinct strategy that uses molecular glues, i.e., autophagosometethering compounds (ATTECs) [33,34]. By performing small-molecule-microarray-based screening, they identified compounds that bind to both the autophagosome-resident LC3 protein and the mutant huntingtin protein (mHTT), but not with the wild-type HTT protein. mHTT causes Huntington's disease, which is an incurable neurodegenerative disorder. Besides mHTT, ATTEC can target another disease-causing protein with the expanded polyglutamine stretch, including ataxin-3, and reduce its level.

The Bertozzi group developed lysosome-targeting chimeras (LYTACs) that direct extracellular and membrane proteins for degradation via the endolysosomal pathway. They designed and synthesized LYTACs that consist of a small-molecule or an antibody that binds to a POI and a chemically synthesized glycopeptide ligand that binds to the cation-independent mannose-6-phosphate receptor (CI-M6PR), which is a cell-surface lysosome-shuttling receptor (Figure 2d) [35]. LYTAC recruits the POI on the cell-surface to CI-M6PR and triggers endocytosis, followed by lysosomal degradation. Although CI-M6PR is ubiquitously expressed in various tissues, there are other classes of lysosometrafficking receptors that show a tissue-specific expression pattern, inspiring further research to develop a second class of LYTAC technology. The same group focused on the asialoglycoprotein receptor, a liver-specific lysosome-targeting receptor, which induces clathrin-mediated endocytosis [36]. They conjugated binders of the POI to a triantenerrary $\mathrm{N}$-acetylgalactosamine (tri-GalNAc) motif that engages the asialoglycoprotein receptor to induce the degradation of the target protein. This GalNAc-LYTAC technology achieves tissue-specific degradation, which could be beneficial for future therapeutic applications.

\section{Conditional Control of Protein Stability Using Genetic Manipulation}

Another strategy for the post-translational control of protein expression is the genetic conjugation of a degradation tag to the target protein. A degron is a minimal sequence within a protein that can be targeted by a proteolytic machinery [37]. The degron is transferable; thus, its genetic fusion to other proteins confers instability to the entire fusion protein. The technologies described below are summarized in Table 2.

\subsection{Small-Molecule-Switchable Degrons}

The representative work of small-molecule-based degron technology is the destabilizing domain (DD) developed by the Wandless group. An engineered variant of the 
human FK506- and rapamycin-binding protein (FKBP12), FKBP12 F36V, possesses a "hole" that allows a "bumped" ligand, Shield-1, to bind more tightly to the F36V mutant compared with the wild-type protein, by almost three orders of magnitude. Using random mutagenesis, they identified mutants of FKBP12 F36V that are unfolded, ubiquitinated, and rapidly and constitutively degraded when expressed in mouse and human-derived cells [38]. These domains are called destabilizing domains (DDs), and this instability is conferred to other proteins fused to these DDs. The addition of Shield-1, which binds to the FKBP12 DD and stabilizes the DD protein fold, rescues them from degradation, allowing fusion proteins to perform their functions (Figure 3a). This "drug-on" system is reversible and tunable, as well as useful for the study of constitutively active enzymes. Those authors further created orthogonal DDs using a combination of Escherichia coli dihydrofolate reductase [39], the human estrogen receptor ligand-binding domain [40], or the bilirubin-binding protein (UnaG) [41], and their ligands. In addition to reversibility and tunability, the drug-dependent stabilization of the target protein is an important feature of the DD technology. It has been shown that the DD approach works in several organisms [42-47]. Although this is useful for the study of constitutively active enzymes, etc., it requires the continuous exposure of the stabilizing ligand to the cells, for protein expression. The authors established a complementary technique with a ligand-induced degradation (LID) domain in which a 19-amino-acid degron is fused to the $C$ terminus of FKBP12 F36V (Figure 3b) [48]. In the absence of Shield-1, the degron is bound to FKBP12 $\mathrm{F} 36 \mathrm{~V}$ and the fusion protein is stable. In turn, the addition of Shield-1, which binds to FKBP12 F36V and displaces the degron, induces the degradation of the fusion protein.

Fusion proteins with tags can be targeted for degradation via recruitment to specific E3 Ub ligases using chimeric molecules such as PROTAC and SNIPER. These techniques are based on the inducible proximity between the POI and the E3 ligase using a Halo tag, which is a modified haloalkene dehalogenase designed to covalently bind to the synthetic ligand (Halo tag ligand). The Crews group developed HaloPROTACs that contain a ligand for HaloTag conjugated to POIs and a ligand for the VHL E3 Ub ligase [49]. HaloPROTACs bind to both the HaloTag conjugated to POIs and the VHL E3 Ub ligase, leading to the ubiquitination and degradation of the fusion protein with POIs (Figure 3d). This group also developed a hydrophobic tagging (Hyt) strategy using the HaloTag fusion protein system [50]. A hydrophobic group of the misfolded protein is exposed on its surface, to be recognized by the 70-kDa heat-shock protein (HSP70), which specifically binds hydrophobic amino acids and helps the folding of slow-folding proteins (Figure 3c) [51]. When a misfolded protein is not properly folded into its native structure by HSP70, the complex of HSP70 and substrate is recognized by CHIP, which is a chaperone-dependent E3 Ub ligase, resulting in degradation. Based on the mechanism in which a protein carrying a hydrophobic tag can mimic the misfolded protein, they designed and synthesized a smallmolecule with an adamantyl moiety to bind a HaloTag protein. A HaloTag fusion protein is degraded by addition of the hydrophobic-tagged molecule with adamantly moiery. In addition, Gao et al. used the HyT method to reduce the level of the microtubule-associated protein Tau, which is related to Alzheimer's disease [52]. They designed and synthesized a chimeric molecule that consists of an adamantyl moiety, a Tau-recognition motif, and a cell-penetrating peptide motif. Analogously, Nabet et al. developed a degradation tag (dTAG) system [53]. They generated dTAG molecules that consist of AP1867, a bumped ligand for FKBP12 F36V, and a ligand for the CRBN E3 Ub ligase (Figure 3d). The dTAG molecules bind to both FKBP12 F36V conjugated to the POI and the CRBN E3 Ub ligase, causing ubiquitination and degradation of the fusion proteins with FKBP12 F36V. 
(a) destabilizing domain (DD)

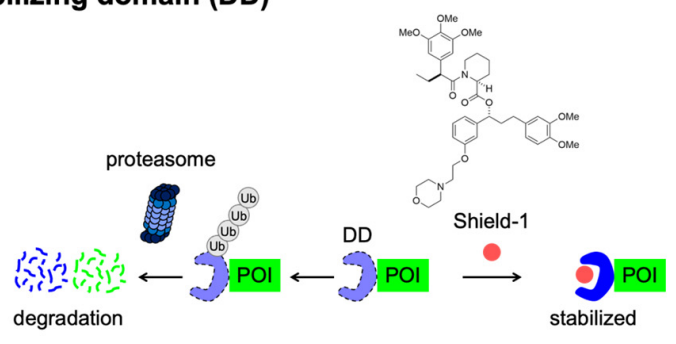

(b) ligand-induced degradation (LID)

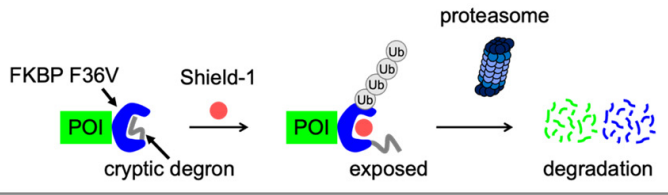

(c) hydrophobic tag (HyT)

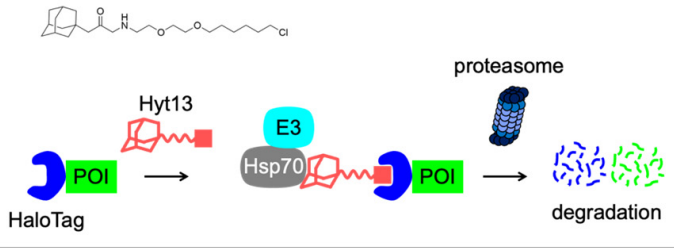

(d) degradation tag (dTAG) / HaloPROTAC

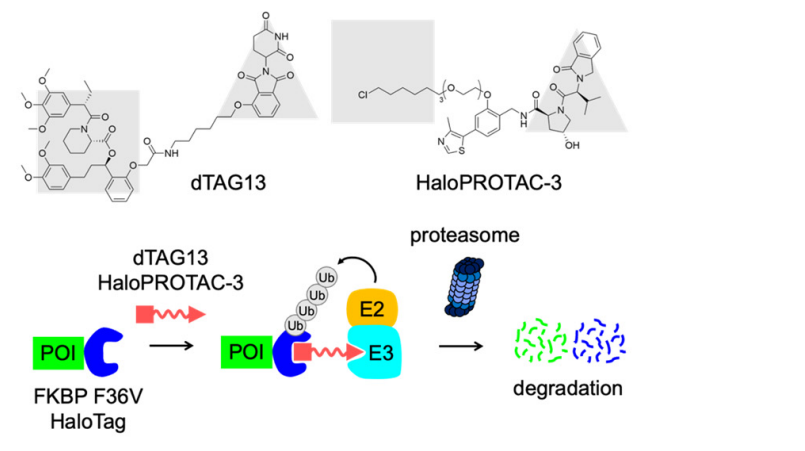

(e) auxin-inducible degron (AID)

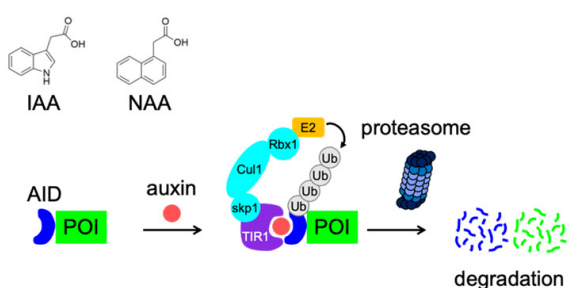

(f) IMiD-induced degron

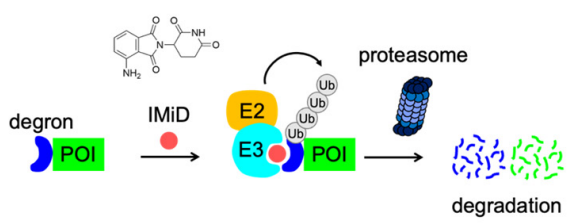

Figure 3. Small-molecule-switchable degrons. Concepts of (a) DD, (b) LID, (c) HyT, (d) dTAG/ HaloPROTAC, (e) AID, and (f) IMiD-induced degron. 
Molecular glues that recruit E3 $\mathrm{Ub}$ ligases to the substrate can also be a powerful tool for inducing proximity between a POI and an E3 ligase. One of the advantages of molecular glues, compared with the chimeric bifunctional molecule, is the structural simplicity of the degradation inducer, which provides improved solubility compared with bifunctional molecules, and may be beneficial for therapeutic applications. A representative example of a molecular-glue-based approach is the auxin-inducible degron (AID) system, in which the auxin-dependent degradation pathway is transposed to other eukaryotic cells [54]. The plant hormone auxin (e.g., indole-3-acetic acid (IAA)) binds to the F-box transport inhibitor response 1 (TIR1) protein and induce the interaction between SCF-TIR1 and the auxin or IAA (AUX/IAA) transcription repressors. SCF-TIR1 recruits an E2 Ub-conjugating enzyme, resulting in ubiquitination and degradation. The F-box protein in SCF determines substrate specificity in all eukaryotes, whereas TIR1 and AUX/IAAs exist only in plant species. In cells co-expressing TIR1 and an AID conjugated to POI, auxins recruit SCF-TIR1 to the AID fusion protein, leading to ubiquitination and degradation (Figure 3e). The AID technology can be applied to the study of various organisms, including mice $[55,56]$, yeast [54,57], Drosophila melanogaster [58], and Caenorhabditis elegans [59]. However, the AID system suffers from leaky degradation in the absence of auxin and requires a high dose of auxin for effective degradation. Recently, the Ikonen group reported an improved system using auxin-receptor F-box protein AtAFB2 and the short degron miniIAA7, to achieve rapid and efficient degradation with minimal basal depletion in the absence of the IAA compound [60]. Furthermore, the Kanemaki and Fukagawa groups improved the AID system using engineered bumped-auxin and holed-TIR1 pairs via a bump-and-hole strategy [56,61]. The improved AID system induces effective degradation at a lower dose of auxin and shows no detectable leaky degradation.

There is a distinct type of molecular glue-based technology which relies on thalidomidelike molecules (called IMiDs). IMiDs recruit the celebron $\mathrm{Ub}$ ligase complex to its substrates, such as IKAROS family zinc finger 3 (IKZF3) and Sal-like protein 4 (SALL4), thus resulting in the proteasomal degradation (Figure 3f). The substrate specificity of celebron is dependent on the structure of IMiDs, which achieve the selective degradation of the target protein tagged with IKZF3 or SALL4. The advantage of IMiDs-based-technologies is the use of FDA-approved drugs, such as pomalidomide, which may be a potential benefit for the future therapeutic application of these techniques. Another feature of IMiDs-induced degrons is that their size is relatively small compared with other degrons. Koduri et al. screened the minimal IMiD-responsive IKZF3 degron and showed that this peptidic degron can be used to target fusion proteins for degradation in the presence of IMiDs [62] Yamanaka et al. also developed another IMiD-induced protein degradation system using a SALL4-derived degron [63]. Unlike the IKZF3 degron, the SALL4-based degron peptide can work in either the $\mathrm{N}$ - or C-terminus of the target protein.

\subsection{Light-Switchable Degrons}

Alternatively, degron activity can be controlled by light irradiation. The light oxygen voltage (LOV2) domain of phototropin consists of a flavin mononucleotide-binding core domain and the C-terminal J $\alpha$-helix. Blue light irradiation causes a covalent reaction between a cysteine of the core domain and the flavin mononucleotide (FMN), and induces a conformational change within the core. Then, the J $\alpha$-helix is unfolded and dissociated from the LOV2 domain (Figure 4a). The LOV2 domain technologies are based on the attachment of the degron sequence to the end of the Ja-helix, which can control protein activity by light. Renicke et al. developed a generic photosensitive degron by fusing the Arabidopsis thaliana LOV2 domain of phototropin 1 to a degron derived from the murine ornithine decarboxylaselike degradation sequence (ODC) (Figure 4a) [64], which can be degraded by the $20 \mathrm{~S}$ proteasome [65]. When the photosensitive degron is fused to the $\mathrm{C}$ terminus of a POI, the J $\alpha$-helix interacts with the LOV2 domain in the dark state, whereas blue light irradiation causes the C-terminal J $\alpha$-helix to dissociate from the LOV2 domain, thus revealing the ODC degron and inducing the degradation of the fusion protein. The 
Wandless group also developed a conditional blue light inducible degradation (B-LID) domain by fusing a mutant of the Avena sativa LOV2 domain to a small peptide degron, RRRGN (Figure 4a) [66].

\section{(a) photosensitive degron/}

blue-light inducible degradation (B-LID)

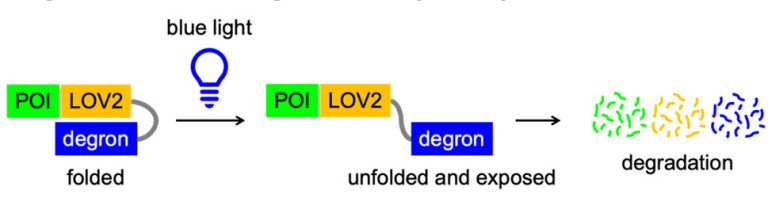

\section{(b) generalizable light-modulated protein stabilization system} (GLIMPSe)

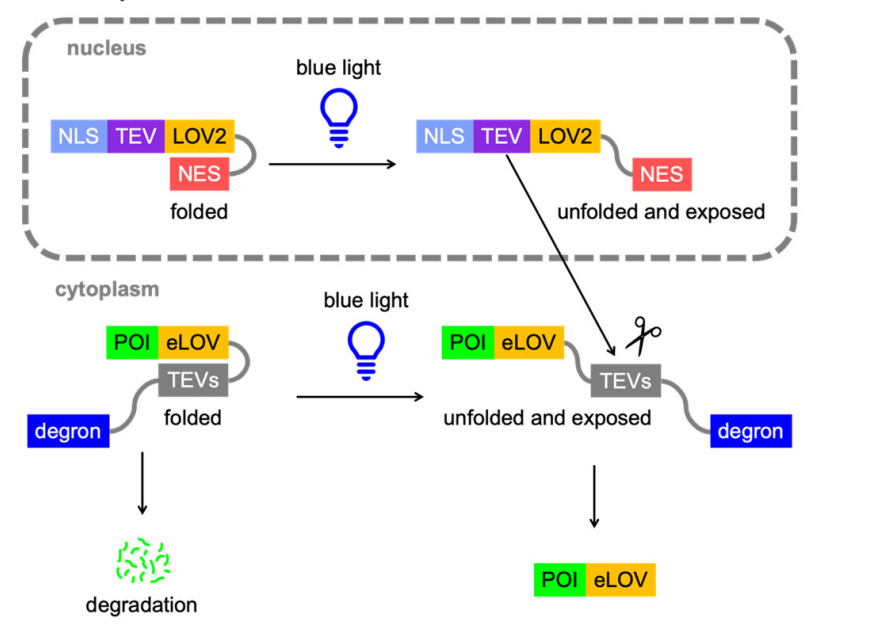

(c) small-molecule-dependent photolytic peptide

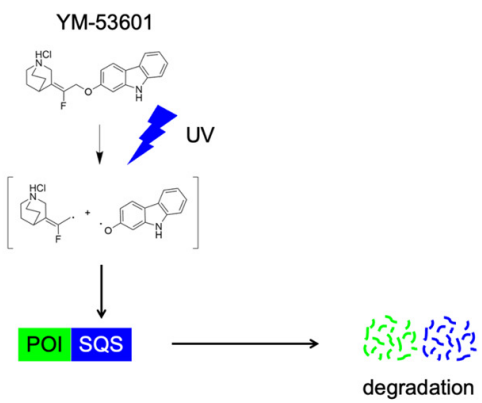

Figure 4. Light-switchable degrons. Concepts of (a) photosensitive degron and B-LID, (b) generalizable light-modulated protein stabilization system (GLIMPSe), and (c) small-molecule-dependent photolytic peptide.

Mondal et al. developed another optogenic system, named generalizable lightmodulated protein stabilization system (GLIMPSe), using the Deadend (Dnd) protein, which is a degron derived from Xenopus laevis, in conjunction with two optogenetic modules; the light-inducible nuclear export system (LEXY), and evolved LOV (eLOV) (Figure 4b) [67]. The LEXY protein includes a nuclear localization signal (NLS), a TEV protease, a LOV2 domain, and a nuclear export signal (NES). In the dark state, the NLS dominates because of the caging of the NES; therefore, the LEXY protein is anchored into the nucleus. Similarly, the fusion protein containing the POI and TEV recognition sequence (TEVs) is processively degraded in the cytoplasm by the proteasome because of the degron activity of the Dnd protein. Blue light irradiation causes a conformational change in eLOV and facilitates its dissociation from the TEVs. Simultaneously, the NES in the LEXY protein in the nucleus is 
also uncaged, resulting in the export of this protein into the cytoplasm. The exposed TEV protease of the LEXY protein cleaves the TEVs, thus releasing the POI-eLOV fusion protein.

Takemoto et al. found that YM-53601, which is a small-molecule inhibitor of squalene synthase (SQS), selectively degrades SQS upon UV irradiation [68]. They demonstrated that the light-induced degradation of SQS requires its short C-terminal peptide. When the SQS peptide was fused to target proteins at either the $\mathrm{N}$ or $\mathrm{C}$ terminus, the fusion proteins were selectively degraded upon both YM-53601 and UV exposure. UV irradiation induces the homolytic $\mathrm{C}-\mathrm{O}$ bond cleavage of YM-53601, which generates radical species and abstracts hydrogen atoms from the SQS peptide, thus resulting in the degradation of the fusion protein.

\subsection{Nanobody-Based Degrons}

Degradation tools that use specific reagents for the detection of the target protein have been emerging. These methods rely on single-domain-binding proteins, such as the heavy-chain antibodies from Camelidae sp. (called nanobodies) [69] or the designed ankyrin repeat proteins (DARPins) [70]. Unlike antibodies, these single-domain proteins can be expressed by a single vector system, which is useful for biological studies. Caussinus et al. developed a genetically encoded method for the direct and fast depletion of the target green fluorescent protein (GFP), called degrade green fluorescent protein (deGradFP) (Figure 5a) [71]. The deGradFP system utilizes a nanobody against GFP, called VhhGFP4, which can be fused with NSlmb, an F-box domain included in the N-terminal part of the F-box protein supernumerary limbs (Slmb) from D. melanogaster. The engineered NSlmbVhhGFP protein recruits the SCF complex to the GFP-tagged protein and subsequently ubiquitinates it, thus allowing easy monitoring of the protein removal process. Ludwicki et al. reported a similar approach, named ubiquibody, that uses a fusion protein comprising E3 ligase mimics from a bacterial pathogen and a fibronectin type III monobody that binds to GFP [72]. This achieves the selective degradation of GFP-tagged proteins in conjunction with hijacking of the mammalian ubiquitin-proteasome pathway. Furthermore, Daniel et al. combined the advantages of the auxin- and nanobody-based degradation technologies to create an AID-VhhGFP fusion for the degradation of GFP-tagged proteins in different cellular structures in a conditional and reversible manner in human cells [73].

(a) degrade Green Fluorescent Protein (deGradFP)

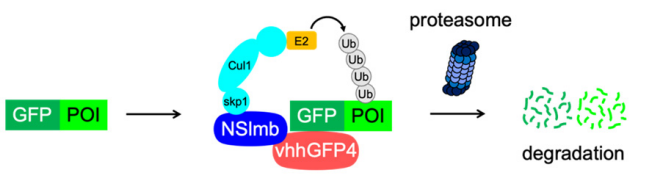

(b) light induced protein depletion (LiPD)

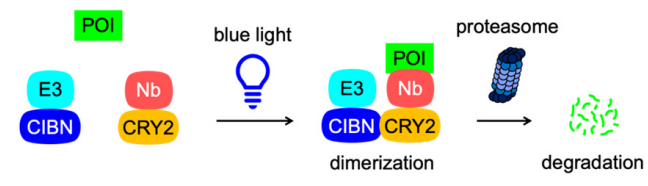

(c) drug-induced protein depletion (DiPD)

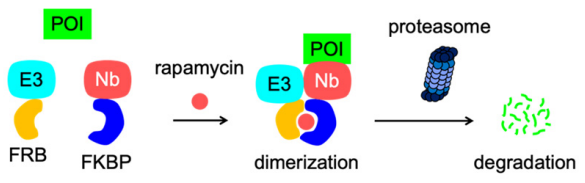

Figure 5. Nanobody-based degrons. Concepts of (a) deGradFP, (b) LiPD, and (c) DiPD. Nanobody $(\mathrm{Nb})$. 
Table 2. Comparison of the technologies used for the conditional control of protein stability using genetic engineering.

\begin{tabular}{|c|c|c|c|c|c|}
\hline Degron Technology & Tag Size & Switch & $\begin{array}{c}\text { Number of } \\
\text { Component(s) }\end{array}$ & Features & References \\
\hline DD & $\begin{array}{l}\text { FKBP DD (12 kDa), DHFR } \\
\text { DD (18 kDa), etc. }\end{array}$ & $\begin{array}{l}\text { Shield-1 (FKBP DD), } \\
\text { TMP (DHFR DD), etc. }\end{array}$ & 1 & $\begin{array}{l}\text { Drug-induced protein } \\
\text { stabilization }\end{array}$ & [38-41] \\
\hline LID & FKBP F36V-degron (13 kDa) & Shield-1 & 1 & $\begin{array}{c}\text { Drug-induced protein } \\
\text { degradation }\end{array}$ & [48] \\
\hline HaloPROTAC & Halo tag (34 kDa) & HaloPROTAC-3 & 1 & $\begin{array}{c}\text { Drug-induced protein } \\
\text { degradation }\end{array}$ & [49] \\
\hline HyT & Halo tag (34 kDa) & Hyt13 & 1 & $\begin{array}{c}\text { Drug-induced protein } \\
\text { degradation }\end{array}$ & [50] \\
\hline dTAG & FKBP F36V (12 kDa) & dTAG13 & 1 & $\begin{array}{c}\text { Drug-induced protein } \\
\text { degradation }\end{array}$ & [53] \\
\hline AID & $\begin{array}{c}\text { AID/IAA }(25 \mathrm{kDa}), \text { mAID } \\
(7 \mathrm{kDa})\end{array}$ & Auxin (IAA, NAA) & 2 & $\begin{array}{c}\text { Drug-induced protein } \\
\text { degradation }\end{array}$ & [54] \\
\hline $\begin{array}{l}\text { IMiD-induced } \\
\text { degron }\end{array}$ & $\begin{array}{l}\text { IKZF3-based degron (6 kDa), } \\
\text { SALL4 degron }(3 \mathrm{kDa})\end{array}$ & $\begin{array}{l}\text { IMiD (thalidomide, } \\
\text { pomalidomide, 5- } \\
\text { hydroxythalidomide) }\end{array}$ & 1 & $\begin{array}{l}\text { Drug-induced protein } \\
\text { degradation }\end{array}$ & {$[62,63]$} \\
\hline $\begin{array}{l}\text { Photosensitive } \\
\text { degron/B-LID }\end{array}$ & LOV2-degron (20 kDa) & Blue light & 1 & $\begin{array}{l}\text { Light-induced protein } \\
\text { degradation }\end{array}$ & {$[65,66]$} \\
\hline GLIMPSe & $\begin{array}{l}\text { eLOV-TEVs-degron } \\
(27 \mathrm{kDa})\end{array}$ & Blue light & 2 & $\begin{array}{l}\text { Light-induced protein } \\
\text { stabilization }\end{array}$ & [67] \\
\hline $\begin{array}{l}\text { Small-molecule- } \\
\text { dependent } \\
\text { photolytic peptide }\end{array}$ & $\begin{array}{l}\text { SQS C-terminal peptide } \\
\quad 371-417(3 \mathrm{kDa})\end{array}$ & YM-53601 \& UV & 1 & $\begin{array}{l}\text { Drug-and UV-induced protein } \\
\text { degradation, no use of cellular } \\
\text { degradation mechanisms }\end{array}$ & [68] \\
\hline deGradFP & GFP (25 kDa) & NA & 2 & $\begin{array}{l}\text { Protein degradation upon } \\
\text { expression of the F-box } \\
\text { protein, anti-GFP nanobody, } \\
\text { no need to attach tags to POIs }\end{array}$ & [71] \\
\hline LiPD & NA & Blue light & 2 & $\begin{array}{l}\text { Light-induced protein } \\
\text { degradation, no need to attach } \\
\text { tags to POIs }\end{array}$ & [74] \\
\hline DiPD & NA & Rapamycin & 2 & $\begin{array}{c}\text { Drug-induced protein } \\
\text { degradation, no need to attach } \\
\text { tags to POIs }\end{array}$ & [74] \\
\hline SURF & $\begin{array}{l}3 \times \text { FRB degron-Ub-C } \\
(58 \mathrm{kDa})\end{array}$ & Rapamycin & 2 & $\begin{array}{l}\text { Drug-induced protein } \\
\text { stabilization, tag removal via } \\
\text { endogenous protease activity }\end{array}$ & [75] \\
\hline SMASh & SMASh tag (34 kDa) & $\begin{array}{c}\text { HCV protease } \\
\text { inhibitors (ASV, CLV) }\end{array}$ & 1 & $\begin{array}{l}\text { Drug-induced protein } \\
\text { degradation, tag removal } \\
\text { via intramolecular } \\
\text { protease activity }\end{array}$ & [76] \\
\hline LIBRON & $\begin{array}{l}\text { FKBP DD-Ub (20 kDa) } \\
\text { DHFR DD-Ub (27 kDa) }\end{array}$ & $\begin{array}{c}\text { Shield-1 (FKBP } \\
\text { DD-Ub), TMP (DHFR } \\
\text { DD-Ub) }\end{array}$ & 1 & $\begin{array}{l}\text { Drug-induced protein } \\
\text { stabilization, tag removal via } \\
\text { endogenous protease activity }\end{array}$ & [77] \\
\hline
\end{tabular}

Recently, Deng et al. developed alternative nanobody-based approaches to control endogenous molecules in cells and organisms via light- or drug-induced protein depletion (LiPD or DiPD, respectively) [74]. These systems comprise two recombinant elements, i.e., the E3 ligase and the nanobody (or DARPin) that target the POI. The two proteins are conjugated with heterodimerization tags, such as cryptochrome 2 (CRY2) and CIBN, thus allowing light-induced heterodimerization between the two fusion proteins (Figure $5 b$ ). This brings together the nanobody-bound POI and the E3 Ub ligase, thus triggering ubiquitination and degradation of the target protein. The RING domain of the E3 Ub ligase and nanobody for POIs can also be fused to FRB and FKBP12, respectively. Upon addition of rapamycin, FRB and FKBP12 heterodimerize, which leads to the ubiquitination and degradation of the POIs (Figure 5c). 


\subsection{Excisable Degrons}

Most of the methods that use the degrons mentioned above, with the exception of LiPD and DiPD, require permanent fusion with degrons at the $\mathrm{N}$ or $\mathrm{C}$ terminus of the POI. The terminal region of the protein often encodes an important sequence that is indispensable for proper function, such as post-translational modification or interaction with other proteins. This prompted researchers to develop excisable degrons that allow the release of target proteins from degrons. Pratt et al. developed the split $\mathrm{Ub}$ for rescue of function (SURF) system [75], in which cells express a fusion protein of FKBP12 with the Ub N-terminal fragment and a fusion protein of three copies of the FRB mutant W2101F (used as a degron) to the Ub C-terminal fragment, followed by the POI (Figure 6a). Rapamycin induces the dimerization of FKBP12 and FRB mutant, to allow $\mathrm{Ub}$ fragment complementation. The $\mathrm{Ub}$ domain is cleaved by cellular DUBs, releasing the POI from the FRB mutant. The SURF system allows the conditional control of protein stability in native from, but requires dimerization of two elements in conjunction with transduction of multiple genes.

(a) split ubiquitin for the rescue of function (SURF)

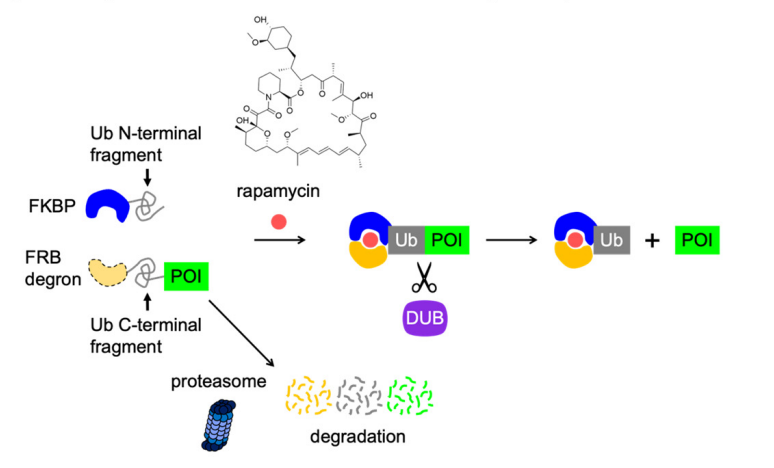

(b) small-molecule-assisted shutoff (SMASh)
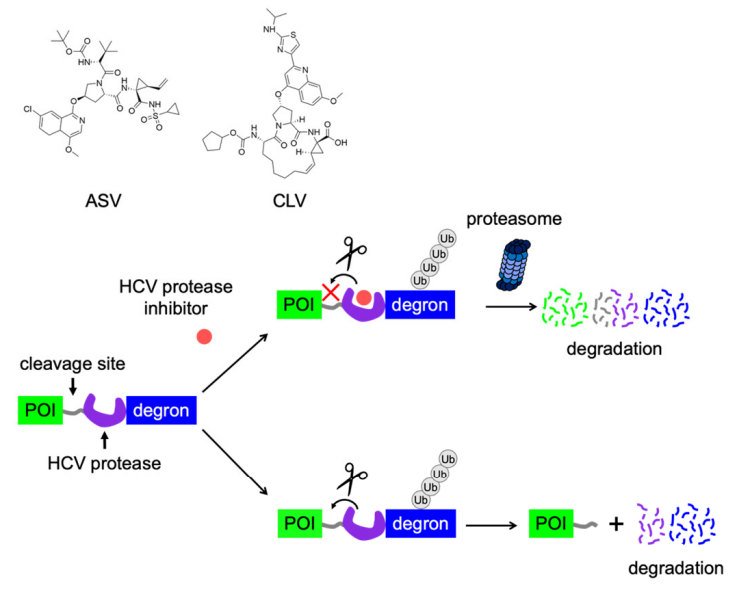

(c) liberation-prone degron (LIBRON)

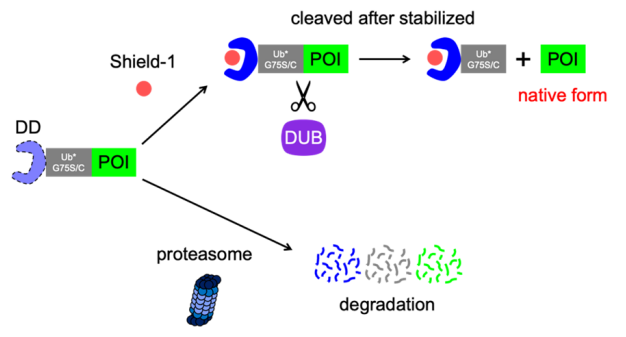

Figure 6. Excisable degrons. Concepts of (a) SURF, (b) SMASh, and (c) LIBRON. 
Chung et al. developed small-molecule-assisted shutoff (SMASh), which is a singleligand/single-domain technique [76]. In this methodology, the POI is fused with the hepatitis $\mathrm{C}$ virus (HCV) nonstructural protein 3 (NS3) protease domain, followed by hydrophobic sequences of HCV NS4A, which are employed as a degron (Figure 6b). In the ligand-free state, an untagged POI is generated through cleavage via internal HCV NS3 protease activity; in turn, the cleavage can be blocked by the addition of an HCV protease inhibitor, either ciluprevir (CLV) or asunaprevir (ASV), thus inducing degradation of the fusion proteins. Despite being an elegant strategy, this technique does not compensate for the release of the completely native form of the protein, as amino acids of the proteaserecognition site remain in the POI after the removal of the degron.

Recently, our group published a method to conditionally control protein stability in native or near-native form. This method combines the destabilizing domain (DD) technology with the enzymatic action of the abundant cellular DUBs, thus allowing the liberation of the POI from the degron tag, which is termed a liberation-prone degron (LIBRON) (Figure 6c) [77]. We introduced a lysine-free $\mathrm{Ub}$ variant (referred to as $\mathrm{Ub}^{*}$ ) as a cleavage tag between the $C$ terminus of the DD and the $\mathrm{N}$ terminus of the POI. The rationale behind the LIBRON system consists of tuning the cleavage speed of the DUB enzyme as an $\mathrm{Ub}$ with a wild-type $\mathrm{C}$ terminus sequence is cotranslationally processed by an abundant cellular enzyme. We found that G75S/C mutations yielded moderate resistance to DUB cleavage, which compensated for the control of protein degradation. When the $\mathrm{Ub}^{*} \mathrm{G} 75 \mathrm{~S} / \mathrm{C}$ mutants are inserted as cleavage tags between the DD and the POI, the entire fusion protein is degraded because of the instability of the DD when expressed in mammalian cells. The addition of a stabilizing ligand bound to the DD rescues it from degradation, followed by the release of the POI from C-terminus site of the DD-Ub*G75S/C tag. The LIBRON system is useful for the conditional regulation of proteins that require unmodified N-termini for their functionality.

\section{Applications}

As described in the previous section, several research teams have generated bifunctional molecules and degron systems for the control of protein degradation at the posttranslational level. Concomitantly, researchers have attempted to apply these technologies to the therapy of diseases and the development of research tools. In this section, we will introduce some of these applications.

\subsection{Drug Discovery}

Many conventional small-molecule drugs inhibit the function of target proteins by binding to the ligand-binding sites of receptors, catalytic sites of enzymes, or functional interaction sites, thereby exerting pharmacological effects. Proteins without "inhibitory sites", such as transcription factors, non-enzymatic proteins, and scaffolding proteins, account for about $80 \%$ of the human proteome $[78,79]$. Those proteins are "undruggable" because they are challenging targets for conventional small-molecule drugs. The PROTAC concept of inducing protein degradation has emerged and has shown potential to overcome the limitations of small-molecule inhibitors [80]. The mechanism of action of PROTAC, which recruits an E3 ligase to the target protein, is based on the simultaneous transient interaction of the target protein with the E3 ligase; PROTAC does not need to inhibit the function of the target protein and is, therefore, effective even for undruggable proteins. Furthermore, PROTAC repeats the dissociation from the target protein after ubiquitination and the binding to the new target protein, which decreases the amount of the target protein over time, thus eliminating the need to maintain high drug concentrations to achieve the desired effect. A recently developed approach to quantitatively detect live-cell kinetic degradation of PROTAC will facilitate the further development, profiling, and improvement of these technologies [81]. Examples of drug discovery directed at target protein degradation are as follows: bromodomain-containing protein 4 (BRD4) is a transcriptional coactivator and a potential therapeutic target in cancer. The Crews and Bradner groups, 
respectively designed BRD4 degraders by linking a small BRD4 inhibitor and a ligand for the E3 ligase cereblon [82,83]. A recent review provides a comprehensive overview of development of PROTAC and its potential application for cancer therapy [84]. Trials are also underway to apply the PROTAC concept to drug discovery for the therapy of neurodegenerative diseases. A common feature of neurodegenerative diseases, such as Alzheimer's, Parkinson's, and Huntington's diseases, is the accumulation of abnormal proteins, i.e., tau, $\alpha$-synuclein, and mutant huntingtin, respectively, in neurons. These abnormal proteins are cytotoxic, and their accumulation causes cell death. Silva et al. transformed a positron emission tomography tracer that binds to pathological tau for diagnostic use into a degrader of pathological tau by linking it to a pomalidomide recruiting the E3 ligase CRBN [85]. Qu et al. designed and synthesized a peptide-based degrader of $\alpha$-synuclein that consists of residues $36-45$ of $\beta$-synuclein as an $\alpha$-synuclein-binding domain, and four amino acids (RRRG) as a proteasome-targeting motif, in conjunction with residues $47-57$ of the trans-activating transcriptional activator protein of the human immunodeficiency virus, as a membrane-penetrating motif [86]. Ishikawa and colleagues developed small hybrid molecules consisting of a neurodegenerative disease diagnostic agent, such as thioflavin $T$, which binds specifically to the cross- $\beta$-sheet structure of aggregated proteins, and a ligand for the E3 ligase cIAP1, and showed that it induces the degradation of $\mathrm{mHtt}$ aggregates [87].

\subsection{Gene and Cell Therapies}

Several research groups and pharmaceutical companies are working on the application of not only PROTAC, but also degrons, for human therapeutic use. Presently, a strategy for the therapy of diseases using artificial therapeutic cells is attracting attention. Chimeric antigen receptor $\mathrm{T}$ cell (CART) therapy is an advancing immunotherapy in the adoptive cell transfer field. In this therapy, T cells collected from a patient's peripheral blood are genetically engineered ex vivo to express chimeric antigen receptor (CAR) proteins on their cell membranes, which are then transferred into the patient. The $\mathrm{T}$ cells are genetically engineered ex vivo to recognize tumor-specific antigens expressed on the surfaces of tumor cells. CART is activated through binding to the tumor-specific antigen, and then kills the tumor cells by releasing cytokines (Figure 7a). CAR is a synthetic membrane protein consisting of an extracellular antigen-binding domain, an extracellular spacer, a transmembrane domain, a costimulation domain, and a T cell activation domain [88,89]. A strategy that allows reversible and variable control of CAR expression would be therapeutically beneficial to avoid toxicities caused by excessive immune responses, such as cytokine release syndrome (CRS). Juillerat et al. showed that the use of the SMASh system allows the regulation of CAR expression and function in cells [90]. Richman et al. showed that the LID system enables the regulation of CAR expression and function in vitro and in vivo [91]. Carbonneau et al. generated $\mathrm{T}$ cells expressing a fusion protein of the IKZF3-derived degron attached to the $C$ terminus of CAR19, which recognizes the cancer-specific antigen CD19 [92]. They demonstrated that CAR expression and function could be regulated in a tunable and reversible manner at the cellular and animal levels using CAR19-degron $\mathrm{T}$ cells and lenalidomide, which is a ligand of this degron (Figure $7 \mathrm{~b}$ ). In addition to its side effects, another concern of the CART therapy is the limitation of CART efficacy because of "T cell exhaustion". CART is continuously stimulated by the high antigen load of cancer cells, which triggers CAR tonic signaling. Excessive CAR signaling leads to the overexpression of immune inhibitory proteins because of global transcriptional and epigenetic alterations, resulting in the loss of CART function. This dysfunctional state is described as T cell exhaustion. The Mackall group showed that transient inhibition of CAR signaling by the DD system reverses the phenotypic and transcriptional features of $\mathrm{T}$ cell exhaustion, remodels the exhausted epigenome, and restores the anti-tumor function [93]. 


\section{(a) CART cell therapy}

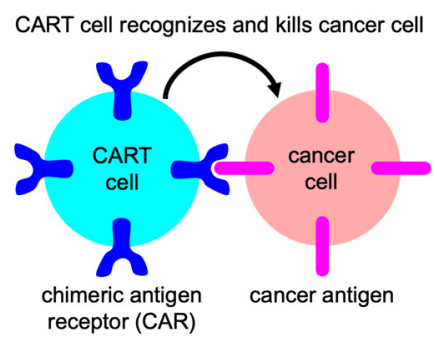

(b) switchable CAR

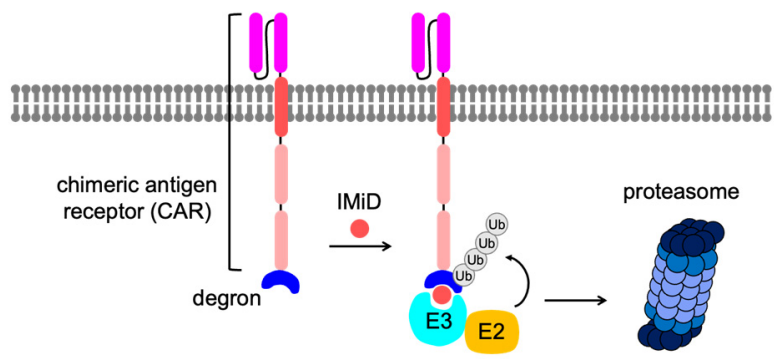

Figure 7. Applications of technologies for post-translational control of protein expression. Schematic diagrams of (a) CART cell therapy and (b) switchable CAR for CART therapy.

\subsection{Research Tools}

In addition to applying degron technology to therapeutics, researchers have combined it with other technologies to develop new research tools. Here, we include three practical examples of this approach. The first application is the combination of degron and CRISPR/Cas9 to control the expression of endogenous proteins. In general, a fusion protein with a degron tag is exogenously expressed by transient or stable transfection. CRISPR/Cas9 can fuse an endogenous gene with a degron tag sequence. Several groups demonstrated that CRISPR/Cas9 enables the knock-in of DD- or AID-tag-fused essential genes, which are difficult to knockout or knockdown, thus allowing the conditional control of endogenous target protein expression [94,95]. Zhu et al. used CRISPR/Cas9 to introduce SMASh-tagged FOXG1 into human pluripotent stem cells, to generate a cellular model of Forkhead transcription factor 1 (FOXG1) syndrome, a disease associated with abnormal protein expression [96]. Such disease models, generated by conditionally manipulating endogenous protein expression, will facilitate the understanding and therapy of human diseases. The second application is the improvement of off-target editing of CRISPR/Cas9 by fusing a degron to the Cas9 protein and controlling the timing and amount of its expression. Cas9 is expressed constitutively, resulting in off-target editing and subsequent genotoxicity. Because off-target editing is often slower than on-target editing, regulating the expression of Cas9 improves on-target editing while avoiding off-target editing and subsequent genotoxicity. Several research groups have demonstrated that controlling Cas9 expression levels reduces off-target editing [97-101]. Furthermore, the Cre protein can also be fused with DD to achieve inducible control of gene expression [102]. The third application is the combination of transcriptional regulation techniques to achieve tighter control of protein expression. The tight conditional control of protein expression requires the simultaneous regulation of their synthesis and degradation. Pedone et al. and $\mathrm{Ng}$ et al., respectively, developed a system for the dual control of protein expression at the transcriptional and post-transcriptional levels $[103,104]$. They combined a tetracycline-inducible system for inducible and reversible transcriptional regulation with DD or AID for targeted protein degradation. 


\section{Conclusions}

This review introduced technologies for the post-translational control of protein expression and their applications. Bifunctional molecules that recruit proteolytic pathways to target proteins have been emerging and being applied to drug discovery and development. This is an attractive approach in drug discovery and development because it does not require the functional inhibition of proteins; it only requires binding capacity and its catalytic mechanism of action makes it effective in low-dose treatments. At present, several challenges remain regarding the development of PROTAC molecules, namely, the rational design of bifunctional molecules and the expansion of the use of various types of $\mathrm{E} 3$ ligases other than the currently used ligases (VHL, CRBN, cIAPs, and MDM2) [105]. Moreover, the precise mechanism of action of the degradation machinery in several techniques, including AUTAC, remains unclear [106,107]. A recent report demonstrated that PROTAC-based polyubiquitination could be facilitated by the thyroid hormone receptor-interacting protein 12 (TRIP12), rather than the hijacking of the enzyme by an E3 ligase binder, thus highlighting a role for TRIP12 as an accelerator of PROTAC-directed degradation [108]. Further research on proteolytic pathways may allow the selection of a proteolytic system according to the characteristics of the target protein. Concomitantly, several research groups generated small-molecule- and light-switchable degrons that can be tagged to target proteins by genetic engineering. The conditional regulation of protein expression using degrons would be more suitable for basic research applications than is the method using bifunctional molecules, because it does not require the design of chemical compounds for each target protein. Another attractive research tool is the regulation of endogenous protein expression via the knock-in of degrons into endogenous proteins using CRISPR/Cas9. This strategy is valuable for loss-of-function studies and the generation of disease models in human pluripotent stem cells. However, there is concern that the degron tag may interfere with the function of the target protein. Therefore, methods such as removable degrons and nanobody-based degrons will continue to newly emerge to control the expression level of target proteins while minimizing the impact on their functions. It may be difficult to precisely control protein expression levels simply by controlling protein degradation using degrons. A combination of methods to regulate protein synthesis by controlling transcription may solve this problem. Although gene therapy and cell therapy have safety issues because of genetic modification, it is possible to prevent their side effects using degrons to control the expression of therapeutic proteins [109]. In the future, bifunctional molecules and degrons will be newly developed or improved. Biomedical research and therapeutic applications will follow.

Author Contributions: Conceptualization, Y.U. and Y.M.; investigation, Y.U. and Y.M.; writingoriginal draft preparation, Y.U.; writing—review and editing, Y.U. and Y.M.; supervision, Y.M.; funding acquisition, Y.M. Both authors have read and agreed to the published version of the manuscript.

Funding: This research was funded by MEXT KAKENHI Grant Number JP 21H00271.

Institutional Review Board Statement: Not applicable.

Informed Consent Statement: Not applicable.

Data Availability Statement: Not applicable.

Acknowledgments: We thank Hidehiko Hirakawa for helpful discussion on the topic.

Conflicts of Interest: The authors declare no conflict of interest.

\section{References}

1. Rakhit, R.; Navarro, R.; Wandless, T.J. Chemical biology strategies for posttranslational control of protein function. Chem. Biol. 2014, 21, 1238-1252. [CrossRef]

2. Cong, L.; Ran, F.A.; Cox, D.; Lin, S.; Barretto, R.; Habib, N.; Hsu, P.D.; Wu, X.; Jiang, W.; Marraffini, L.A.; et al. Multiplex genome engineering using CRISPR/Cas systems. Science 2013, 339, 819-823. [CrossRef] 
3. Mali, P.; Yang, L.; Esvelt, K.M.; Aach, J.; Guell, M.; DiCarlo, J.E.; Norville, J.E.; Church, G.M. RNA-guided human genome engineering via Cas9. Science 2013, 339, 823-826. [CrossRef] [PubMed]

4. Komor, A.C.; Badran, A.H.; Liu, D.R. CRISPR-Based Technologies for the Manipulation of Eukaryotic Genomes. Cell 2017, 168, 20-36. [CrossRef]

5. Sauer, B.; Henderson, N. Site-specific DNA recombination in mammalian cells by the Cre recombinase of bacteriophage P1. Proc. Natl. Acad. Sci. USA 1988, 85, 5166-5170. [CrossRef]

6. Sauer, B. Cre/lox: One more step in the taming of the genome. Endocrine 2002, 19, 221-228. [CrossRef]

7. Le, Y.; Sauer, B. Conditional gene knockout using Cre recombinase. Mol. Biotechnol. 2001, 17, 269-275. [CrossRef]

8. Hart, T.; Chandrashekhar, M.; Aregger, M.; Steinhart, Z.; Brown, K.R.; MacLeod, G.; Mis, M.; Zimmermann, M.; Fradet-Turcotte, A.; Sun, S.; et al. High-Resolution CRISPR Screens Reveal Fitness Genes and Genotype-Specific Cancer Liabilities. Cell 2015, 163, 1515-1526. [CrossRef] [PubMed]

9. Blomen, V.A.; Májek, P.; Jae, L.T.; Bigenzahn, J.W.; Nieuwenhuis, J.; Staring, J.; Sacco, R.; van Diemen, F.R.; Olk, N.; Stukalov, A.; et al. Gene essentiality and synthetic lethality in haploid human cells. Science 2015, 350, 1092-1096. [CrossRef]

10. Teng, X.; Dayhoff-Brannigan, M.; Cheng, W.C.; Gilbert, C.E.; Sing, C.N.; Diny, N.L.; Wheelan, S.J.; Dunham, M.J.; Boeke, J.D.; Pineda, F.J.; et al. Genome-wide consequences of deleting any single gene. Mol. Cell 2013, 52, 485-494. [CrossRef]

11. Gossen, M.; Bujard, H. Tight control of gene expression in mammalian cells by tetracycline-responsive promoters. Proc. Natl. Acad. Sci. USA 1992, 89, 5547-5551. [CrossRef] [PubMed]

12. Kistner, A.; Gossen, M.; Zimmermann, F.; Jerecic, J.; Ullmer, C.; Lübbert, H.; Bujard, H. Doxycycline-mediated quantitative and tissue-specific control of gene expression in transgenic mice. Proc. Natl. Acad. Sci. USA 1996, 93, 10933-10938. [CrossRef] [PubMed]

13. Zhu, Z.; Zheng, T.; Lee, C.G.; Homer, R.J.; Elias, J.A. Tetracycline-controlled transcriptional regulation systems: Advances and application in transgenic animal modeling. Semin. Cell Dev. Biol. 2002, 13, 121-128. [CrossRef]

14. Elbashir, S.M.; Harborth, J.; Lendeckel, W.; Yalcin, A.; Weber, K.; Tuschl, T. Duplexes of 21-nucleotide RNAs mediate RNA interference in cultured mammalian cells. Nature 2001, 411, 494-498. [CrossRef]

15. Aagaard, L.; Rossi, J.J. RNAi therapeutics: Principles, prospects and challenges. Adv. Drug Deliv. Rev. 2007, 59, 75-86. [CrossRef]

16. Sacher, R.; Stergiou, L.; Pelkmans, L. Lessons from genetics: Interpreting complex phenotypes in RNAi screens. Curr. Opin. Cell Biol. 2008, 20, 483-489. [CrossRef]

17. Ravid, T.; Hochstrasser, M. Diversity of degradation signals in the ubiquitin-proteasome system. Nat. Rev. Mol. Cell Biol. 2008, 9 , 679-690. [CrossRef]

18. Ballabio, A.; Bonifacino, J.S. Lysosomes as dynamic regulators of cell and organismal homeostasis. Nat. Rev. Mol. Cell Biol. 2020, 21, 101-118. [CrossRef]

19. Mevissen, T.E.T.; Komander, D. Mechanisms of Deubiquitinase Specificity and Regulation. Ann. Rev. Biochem. 2017, 86, 159-192. [CrossRef]

20. Mizushima, N.; Komatsu, M. Autophagy: Renovation of cells and tissues. Cell 2011, 147, 728-741. [CrossRef]

21. Sakamoto, K.M.; Kim, K.B.; Kumagai, A.; Mercurio, F.; Crews, C.M.; Deshaies, R.J. Protacs: Chimeric molecules that target proteins to the Skp1-Cullin-F box complex for ubiquitination and degradation. Proc. Natl. Acad. Sci. USA 2001, 98, 8554-8559. [CrossRef]

22. Schneekloth, A.R.; Pucheault, M.; Tae, H.S.; Crews, C.M. Targeted intracellular protein degradation induced by a small molecule: En route to chemical proteomics. Bioorg. Med. Chem. Lett. 2008, 18, 5904-5908. [CrossRef] [PubMed]

23. Itoh, Y.; Ishikawa, M.; Naito, M.; Hashimoto, Y. Protein knockdown using methyl bestatin-ligand hybrid molecules: Design and synthesis of inducers of ubiquitination-mediated degradation of cellular retinoic acid-binding proteins. J. Am. Chem. Soc. 2010, 132, 5820-5826. [CrossRef] [PubMed]

24. Atilaw, Y.; Poongavanam, V.; Svensson Nilsson, C.; Nguyen, D.; Giese, A.; Meibom, D.; Erdelyi, M.; Kihlberg, J. Solution Conformations Shed Light on PROTAC Cell Permeability. ACS Med. Chem. Lett. 2021, 12, 107-114. [CrossRef] [PubMed]

25. Lebraud, H.; Wright, D.J.; Johnson, C.N.; Heightman, T.D. Protein Degradation by In-Cell Self-Assembly of Proteolysis Targeting Chimeras. ACS Cent. Sci. 2016, 2, 927-934. [CrossRef]

26. Liu, J.; Chen, H.; Ma, L.; He, Z.; Wang, D.; Liu, Y.; Lin, Q.; Zhang, T.; Gray, N.; Kaniskan, H.; et al. Light-induced control of protein destruction by opto-PROTAC. Sci. Adv. 2020, 6, eaay5154. [CrossRef]

27. Reynders, M.; Matsuura, B.S.; Bérouti, M.; Simoneschi, D.; Marzio, A.; Pagano, M.; Trauner, D. PHOTACs enable optical control of protein degradation. Sci. Adv. 2020, 6, eaay5064. [CrossRef]

28. Cotton, A.D.; Nguyen, D.P.; Gramespacher, J.A.; Seiple, I.B.; Wells, J.A. Development of Antibody-Based PROTACs for the Degradation of the Cell-Surface Immune Checkpoint Protein PD-L1. J. Am. Chem. Soc. 2021, 143, 593-598. [CrossRef]

29. Maneiro, M.A.; Forte, N.; Shchepinova, M.M.; Kounde, C.S.; Chudasama, V.; Baker, J.R.; Tate, E.W. Antibody-PROTAC Conjugates Enable HER2-Dependent Targeted Protein Degradation of BRD4. ACS Chem. Biol. 2020, 15, 1306-1312. [CrossRef]

30. Clift, D.; McEwan, W.A.; Labzin, L.I.; Konieczny, V.; Mogessie, B.; James, L.C.; Schuh, M. A Method for the Acute and Rapid Degradation of Endogenous Proteins. Cell 2017, 171, 1692-1706.e18. [CrossRef]

31. Zeng, J.; Santos, A.F.; Mukadam, A.S.; Osswald, M.; Jacques, D.A.; Dickson, C.F.; McLaughlin, S.H.; Johnson, C.M.; Kiss, L.; Luptak, J.; et al. Target-induced clustering activates Trim-Away of pathogens and proteins. Nat. Struct. Mol. Biol. 2021, 28, 278-289. [CrossRef] [PubMed] 
32. Takahashi, D.; Moriyama, J.; Nakamura, T.; Miki, E.; Takahashi, E.; Sato, A.; Akaike, T.; Itto-Nakama, K.; Arimoto, H. AUTACs: Cargo-Specific Degraders Using Selective Autophagy. Mol. Cell 2019, 76, 797-810.e10. [CrossRef] [PubMed]

33. Li, Z.; Wang, C.; Wang, Z.; Zhu, C.; Li, J.; Sha, T.; Ma, L.; Gao, C.; Yang, Y.; Sun, Y.; et al. Allele-selective lowering of mutant HTT protein by HTT-LC3 linker compounds. Nature 2019, 575, 203-209. [CrossRef] [PubMed]

34. Li, Z.; Zhu, C.; Ding, Y.; Fei, Y.; Lu, B. ATTEC: A potential new approach to target proteinopathies. Autophagy 2020, 16, 185-187. [CrossRef] [PubMed]

35. Banik, S.M.; Pedram, K.; Wisnovsky, S.; Ahn, G.; Riley, N.M.; Bertozzi, C.R. Lysosome-targeting chimaeras for degradation of extracellular proteins. Nature 2020, 584, 291-297. [CrossRef]

36. Ahn, G.; Banik, S.M.; Miller, C.L.; Riley, N.M.; Cochran, J.R.; Bertozzi, C.R. LYTACs that engage the asialoglycoprotein receptor for targeted protein degradation. Nat. Chem. Biol. 2021. [CrossRef] [PubMed]

37. Varshavsky, A. Naming a targeting signal. Cell 1991, 64, 13-15. [CrossRef]

38. Banaszynski, L.A.; Chen, L.C.; Maynard-Smith, L.A.; Ooi, A.G.; Wandless, T.J. A rapid, reversible, and tunable method to regulate protein function in living cells using synthetic small molecules. Cell 2006, 126, 995-1004. [CrossRef] [PubMed]

39. Iwamoto, M.; Bjorklund, T.; Lundberg, C.; Kirik, D.; Wandless, T.J. A general chemical method to regulate protein stability in the mammalian central nervous system. Chem. Biol. 2010, 17, 981-988. [CrossRef]

40. Miyazaki, Y.; Imoto, H.; Chen, L.C.; Wandless, T.J. Destabilizing domains derived from the human estrogen receptor. J. Am. Chem. Soc. 2012, 134, 3942-3945. [CrossRef] [PubMed]

41. Navarro, R.; Chen, L.C.; Rakhit, R.; Wandless, T.J. A Novel Destabilizing Domain Based on a Small-Molecule Dependent Fluorophore. ACS Chem. Biol. 2016, 11, 2101-2104. [CrossRef] [PubMed]

42. Banaszynski, L.A.; Sellmyer, M.A.; Contag, C.H.; Wandless, T.J.; Thorne, S.H. Chemical control of protein stability and function in living mice. Nat. Med. 2008, 14, 1123-1127. [CrossRef] [PubMed]

43. Armstrong, C.M.; Goldberg, D.E. An FKBP destabilization domain modulates protein levels in Plasmodium falciparum. Nat. Methods 2007, 4, 1007-1009. [CrossRef]

44. Herm-Gotz, A.; Agop-Nersesian, C.; Munter, S.; Grimley, J.S.; Wandless, T.J.; Frischknecht, F.; Meissner, M. Rapid control of protein level in the apicomplexan Toxoplasma gondii. Nat. Methods 2007, 4, 1003-1005. [CrossRef]

45. Cho, U.; Zimmerman, S.M.; Chen, L.C.; Owen, E.; Kim, J.V.; Kim, S.K.; Wandless, T.J. Rapid and tunable control of protein stability in Caenorhabditis elegans using a small molecule. PLoS ONE 2013, 8, e72393. [CrossRef]

46. Sethi, S.; Wang, J.W. A versatile genetic tool for post-translational control of gene expression in Drosophila melanogaster. eLife 2017, 6, e30327. [CrossRef] [PubMed]

47. Ramadurgum, P.; Daniel, S.; Hulleman, J.D. Protocol for In Vivo Evaluation and Use of Destabilizing Domains in the Eye, Liver, and Beyond. STAR Protoc. 2020, 1, 100094. [CrossRef]

48. Bonger, K.M.; Chen, L.C.; Liu, C.W.; Wandless, T.J. Small-molecule displacement of a cryptic degron causes conditional protein degradation. Nat. Chem. Biol. 2011, 7, 531-537. [CrossRef]

49. Buckley, D.L.; Raina, K.; Darricarrere, N.; Hines, J.; Gustafson, J.L.; Smith, I.E.; Miah, A.H.; Harling, J.D.; Crews, C.M. HaloPROTACS: Use of Small Molecule PROTACs to Induce Degradation of HaloTag Fusion Proteins. ACS Chem. Biol. 2015, 10, 1831-1837. [CrossRef]

50. Neklesa, T.K.; Tae, H.S.; Schneekloth, A.R.; Stulberg, M.J.; Corson, T.W.; Sundberg, T.B.; Raina, K.; Holley, S.A.; Crews, C.M. Small-molecule hydrophobic tagging-induced degradation of HaloTag fusion proteins. Nat. Chem. Biol. 2011, 7, 538-543. [CrossRef]

51. Kubota, H. Quality control against misfolded proteins in the cytosol: A network for cell survival. J. Biochem. 2009, 146, 609-616. [CrossRef] [PubMed]

52. Gao, N.; Chu, T.-T.; Li, Q.-Q.; Lim, Y.-J.; Qiu, T.; Ma, M.-R.; Hu, Z.-W.; Yang, X.-F.; Chen, Y.-X.; Zhao, Y.-F.; et al. Hydrophobic tagging-mediated degradation of Alzheimer's disease related Tau. RSC Adv. 2017, 7, 40362-40366. [CrossRef]

53. Nabet, B.; Roberts, J.M.; Buckley, D.L.; Paulk, J.; Dastjerdi, S.; Yang, A.; Leggett, A.L.; Erb, M.A.; Lawlor, M.A.; Souza, A.; et al. The dTAG system for immediate and target-specific protein degradation. Nat. Chem. Biol. 2018, 14, 431-441. [CrossRef] [PubMed]

54. Nishimura, K.; Fukagawa, T.; Takisawa, H.; Kakimoto, T.; Kanemaki, M. An auxin-based degron system for the rapid depletion of proteins in nonplant cells. Nat. Methods 2009, 6, 917-922. [CrossRef]

55. Gu, B.; Posfai, E.; Rossant, J. Efficient generation of targeted large insertions by microinjection into two-cell-stage mouse embryos. Nat. Biotechnol. 2018, 36, 632-637. [CrossRef]

56. Yesbolatova, A.; Saito, Y.; Kitamoto, N.; Makino-Itou, H.; Ajima, R.; Nakano, R.; Nakaoka, H.; Fukui, K.; Gamo, K.; Tominari, Y.; et al. The auxin-inducible degron 2 technology provides sharp degradation control in yeast, mammalian cells, and mice. Nat. Commun. 2020, 11, 5701. [CrossRef]

57. Costa, E.A.; Subramanian, K.; Nunnari, J.; Weissman, J.S. Defining the physiological role of SRP in protein-targeting efficiency and specificity. Science 2018, 359, 689-692. [CrossRef]

58. Bence, M.; Jankovics, F.; Lukácsovich, T.; Erdélyi, M. Combining the auxin-inducible degradation system with CRISPR/Cas9based genome editing for the conditional depletion of endogenous Drosophila melanogaster proteins. FEBS J. 2017, 284, 1056-1069. [CrossRef]

59. Zhang, L.; Ward, J.D.; Cheng, Z.; Dernburg, A.F. The auxin-inducible degradation (AID) system enables versatile conditional protein depletion in C. elegans. Development 2015, 142, 4374-4384. [CrossRef] [PubMed] 
60. Li, S.; Prasanna, X.; Salo, V.T.; Vattulainen, I.; Ikonen, E. An efficient auxin-inducible degron system with low basal degradation in human cells. Nat. Methods 2019, 16, 866-869. [CrossRef] [PubMed]

61. Nishimura, K.; Yamada, R.; Hagihara, S.; Iwasaki, R.; Uchida, N.; Kamura, T.; Takahashi, K.; Torii, K.U.; Fukagawa, T. A super-sensitive auxin-inducible degron system with an engineered auxin-TIR1 pair. Nucleic Acids Res. 2020, 48, e108. [CrossRef] [PubMed]

62. Koduri, V.; McBrayer, S.K.; Liberzon, E.; Wang, A.C.; Briggs, K.J.; Cho, H.; Kaelin, W.G., Jr. Peptidic degron for IMiD-induced degradation of heterologous proteins. Proc. Natl. Acad. Sci. USA 2019, 116, 2539-2544. [CrossRef] [PubMed]

63. Yamanaka, S.; Shoya, Y.; Matsuoka, S.; Nishida-Fukuda, H.; Shibata, N.; Sawasaki, T. An IMiD-induced SALL4 degron system for selective degradation of target proteins. Commun. Biol. 2020, 3, 515. [CrossRef] [PubMed]

64. Jariel-Encontre, I.; Bossis, G.; Piechaczyk, M. Ubiquitin-independent degradation of proteins by the proteasome. Biochim. Biophys. Acta 2008, 1786, 153-177. [CrossRef]

65. Renicke, C.; Schuster, D.; Usherenko, S.; Essen, L.O.; Taxis, C. A LOV2 domain-based optogenetic tool to control protein degradation and cellular function. Chem. Biol. 2013, 20, 619-626. [CrossRef] [PubMed]

66. Bonger, K.M.; Rakhit, R.; Payumo, A.Y.; Chen, J.K.; Wandless, T.J. General method for regulating protein stability with light. ACS Chem. Biol. 2014, 9, 111-115. [CrossRef]

67. Mondal, P.; Krishnamurthy, V.V.; Sharum, S.R.; Haack, N.; Zhou, H.; Cheng, J.; Yang, J.; Zhang, K. Repurposing Protein Degradation for Optogenetic Modulation of Protein Activities. ACS Synth. Biol. 2019, 8, 2585-2592. [CrossRef]

68. Takemoto, Y.; Mao, D.; Punzalan, L.L.; Gotze, S.; Sato, S.I.; Uesugi, M. Discovery of a Small-Molecule-Dependent Photolytic Peptide. J. Am. Chem. Soc. 2020, 142, 1142-1146. [CrossRef]

69. Rothbauer, U.; Zolghadr, K.; Tillib, S.; Nowak, D.; Schermelleh, L.; Gahl, A.; Backmann, N.; Conrath, K.; Muyldermans, S.; Cardoso, M.C.; et al. Targeting and tracing antigens in live cells with fluorescent nanobodies. Nat. Methods 2006, 3, 887-889. [CrossRef] [PubMed]

70. Hansen, S.; Stuber, J.C.; Ernst, P.; Koch, A.; Bojar, D.; Batyuk, A.; Pluckthun, A. Design and applications of a clamp for Green Fluorescent Protein with picomolar affinity. Sci. Rep. 2017, 7, 16292. [CrossRef] [PubMed]

71. Caussinus, E.; Kanca, O.; Affolter, M. Fluorescent fusion protein knockout mediated by anti-GFP nanobody. Nat. Struct. Mol. Biol. 2011, 19, 117-121. [CrossRef]

72. Ludwicki, M.B.; Li, J.; Stephens, E.A.; Roberts, R.W.; Koide, S.; Hammond, P.T.; DeLisa, M.P. Broad-Spectrum Proteome Editing with an Engineered Bacterial Ubiquitin Ligase Mimic. ACS Cent. Sci. 2019, 5, 852-866. [CrossRef]

73. Daniel, K.; Icha, J.; Horenburg, C.; Muller, D.; Norden, C.; Mansfeld, J. Conditional control of fluorescent protein degradation by an auxin-dependent nanobody. Nat. Commun. 2018, 9, 3297. [CrossRef] [PubMed]

74. Deng, W.; Bates, J.A.; Wei, H.; Bartoschek, M.D.; Conradt, B.; Leonhardt, H. Tunable light and drug induced depletion of target proteins. Nat. Commun. 2020, 11, 304. [CrossRef] [PubMed]

75. Pratt, M.R.; Schwartz, E.C.; Muir, T.W. Small-molecule-mediated rescue of protein function by an inducible proteolytic shunt. Proc. Natl. Acad. Sci. USA 2007, 104, 11209-11214. [CrossRef] [PubMed]

76. Chung, H.K.; Jacobs, C.L.; Huo, Y.; Yang, J.; Krumm, S.A.; Plemper, R.K.; Tsien, R.Y.; Lin, M.Z. Tunable and reversible drug control of protein production via a self-excising degron. Nat. Chem. Biol. 2015, 11, 713-720. [CrossRef]

77. Miyamae, Y.; Chen, L.C.; Utsugi, Y.; Farrants, H.; Wandless, T.J. A Method for Conditional Regulation of Protein Stability in Native or Near-Native Form. Cell Chem. Biol. 2020, 27, 1573-1581.e3. [CrossRef] [PubMed]

78. Salami, J.; Crews, C.M. Waste disposal-An attractive strategy for cancer therapy. Science 2017, 355, 1163-1167. [CrossRef] [PubMed]

79. An, S.; Fu, L. Small-molecule PROTACs: An emerging and promising approach for the development of targeted therapy drugs. EBioMedicine 2018, 36, 553-562. [CrossRef]

80. Ding, Y.; Fei, Y.; Lu, B. Emerging New Concepts of Degrader Technologies. Trends Pharm. Sci. 2020, 41, 464-474. [CrossRef]

81. Riching, K.M.; Mahan, S.; Corona, C.R.; McDougall, M.; Vasta, J.D.; Robers, M.B.; Urh, M.; Daniels, D.L. Quantitative Live-Cell Kinetic Degradation and Mechanistic Profiling of PROTAC Mode of Action. ACS Chem. Biol. 2018, 13, 2758-2770. [CrossRef]

82. Winter, G.E.; Buckley, D.L.; Paulk, J.; Roberts, J.M.; Souza, A.; Dhe-Paganon, S.; Bradner, J.E. Phthalimide conjugation as a strategy for in vivo target protein degradation. Science 2015, 348, 1376-1381. [CrossRef] [PubMed]

83. Lu, J.; Qian, Y.; Altieri, M.; Dong, H.; Wang, J.; Raina, K.; Hines, J.; Winkler, J.D.; Crew, A.P.; Coleman, K.; et al. Hijacking the E3 Ubiquitin Ligase Cereblon to Efficiently Target BRD4. Chem. Biol. 2015, 22, 755-763. [CrossRef] [PubMed]

84. Qi, S.M.; Dong, J.; Xu, Z.Y.; Cheng, X.D.; Zhang, W.D.; Qin, J.J. PROTAC: An Effective Targeted Protein Degradation Strategy for Cancer Therapy. Front. Pharm. 2021, 12, 692574. [CrossRef] [PubMed]

85. Silva, M.C.; Ferguson, F.M.; Cai, Q.; Donovan, K.A.; Nandi, G.; Patnaik, D.; Zhang, T.; Huang, H.T.; Lucente, D.E.; Dickerson, B.C.; et al. Targeted degradation of aberrant tau in frontotemporal dementia patient-derived neuronal cell models. Elife 2019, 8, e45457. [CrossRef]

86. Qu, J.; Ren, X.; Xue, F.; He, Y.; Zhang, R.; Zheng, Y.; Huang, H.; Wang, W.; Zhang, J. Specific Knockdown of alpha-Synuclein by Peptide-Directed Proteasome Degradation Rescued Its Associated Neurotoxicity. Cell Chem. Biol. 2020, 27, 751-762.e4. [CrossRef]

87. Tomoshige, S.; Nomura, S.; Ohgane, K.; Hashimoto, Y.; Ishikawa, M. Discovery of Small Molecules that Induce the Degradation of Huntingtin. Angew. Chem. Int. Ed. 2017, 56, 11530-11533. [CrossRef] 
88. Chang, Z.L.; Chen, Y.Y. CARs: Synthetic Immunoreceptors for Cancer Therapy and Beyond. Trends Mol. Med. 2017, 23, 430-450. [CrossRef]

89. Kershaw, M.H.; Westwood, J.A.; Darcy, P.K. Gene-engineered T cells for cancer therapy. Nat. Rev. Cancer 2013, 13, 525-541. [CrossRef] [PubMed]

90. Juillerat, A.; Tkach, D.; Busser, B.W.; Temburni, S.; Valton, J.; Duclert, A.; Poirot, L.; Depil, S.; Duchateau, P. Modulation of chimeric antigen receptor surface expression by a small molecule switch. BMC Biotechnol. 2019, 19, 44. [CrossRef] [PubMed]

91. Richman, S.A.; Wang, L.C.; Moon, E.K.; Khire, U.R.; Albelda, S.M.; Milone, M.C. Ligand-Induced Degradation of a CAR Permits Reversible Remote Control of CAR T Cell Activity In Vitro and In Vivo. Mol. Ther. 2020, 28, 1600-1613. [CrossRef]

92. Carbonneau, S.; Sharma, S.; Peng, L.; Rajan, V.; Hainzl, D.; Henault, M.; Yang, C.; Hale, J.; Shulok, J.; Tallarico, J.; et al. An IMiD-inducible degron provides reversible regulation for chimeric antigen receptor expression and activity. Cell Chem. Biol. 2021, 28, 802-812.e6. [CrossRef]

93. Weber, E.W.; Parker, K.R.; Sotillo, E.; Lynn, R.C.; Anbunathan, H.; Lattin, J.; Good, Z.; Belk, J.A.; Daniel, B.; Klysz, D.; et al. Transient rest restores functionality in exhausted CAR-T cells through epigenetic remodeling. Science 2021, 372 , eaba1786. [CrossRef] [PubMed]

94. Park, A.; Won, S.T.; Pentecost, M.; Bartkowski, W.; Lee, B. CRISPR/Cas9 allows efficient and complete knock-in of a destabilization domain-tagged essential protein in a human cell line, allowing rapid knockdown of protein function. PLoS ONE 2014, 9, e95101. [CrossRef] [PubMed]

95. Natsume, T.; Kiyomitsu, T.; Saga, Y.; Kanemaki, M.T. Rapid Protein Depletion in Human Cells by Auxin-Inducible Degron Tagging with Short Homology Donors. Cell Rep. 2016, 15, 210-218. [CrossRef] [PubMed]

96. Zhu, W.; Zhang, B.; Li, M.; Mo, F.; Mi, T.; Wu, Y.; Teng, Z.; Zhou, Q.; Li, W.; Hu, B. Precisely controlling endogenous protein dosage in hPSCs and derivatives to model FOXG1 syndrome. Nat. Commun. 2019, 10, 928. [CrossRef] [PubMed]

97. Senturk, S.; Shirole, N.H.; Nowak, D.G.; Corbo, V.; Pal, D.; Vaughan, A.; Tuveson, D.A.; Trotman, L.C.; Kinney, J.B.; Sordella, R. Rapid and tunable method to temporally control gene editing based on conditional Cas 9 stabilization. Nat. Commun. 2017, 8, 14370. [CrossRef]

98. Sreekanth, V.; Zhou, Q.; Kokkonda, P.; Bermudez-Cabrera, H.C.; Lim, D.; Law, B.K.; Holmes, B.R.; Chaudhary, S.K.; Pergu, R.; Leger, B.S.; et al. Chemogenetic System Demonstrates That Cas9 Longevity Impacts Genome Editing Outcomes. ACS Cent. Sci. 2020, 6, 2228-2237. [CrossRef]

99. Kleinjan, D.A.; Wardrope, C.; Nga Sou, S.; Rosser, S.J. Drug-tunable multidimensional synthetic gene control using inducible degron-tagged dCas9 effectors. Nat. Commun. 2017, 8, 1191. [CrossRef]

100. Wu, Y.; Yang, L.; Chang, T.; Kandeel, F.; Yee, J.K. A Small Molecule-Controlled Cas9 Repressible System. Mol. Ther. Nucleic Acids 2020, 19, 922-932. [CrossRef]

101. Lopez Del Amo, V.; Leger, B.S.; Cox, K.J.; Gill, S.; Bishop, A.L.; Scanlon, G.D.; Walker, J.A.; Gantz, V.M.; Choudhary, A. Small-Molecule Control of Super-Mendelian Inheritance in Gene Drives. Cell Rep. 2020, 31, 107841. [CrossRef]

102. Sando, R., 3rd; Baumgaertel, K.; Pieraut, S.; Torabi-Rander, N.; Wandless, T.J.; Mayford, M.; Maximov, A. Inducible control of gene expression with destabilized Cre. Nat. Methods 2013, 10, 1085-1088. [CrossRef]

103. Pedone, E.; Postiglione, L.; Aulicino, F.; Rocca, D.L.; Montes-Olivas, S.; Khazim, M.; di Bernardo, D.; Pia Cosma, M.; Marucci, L. A tunable dual-input system for on-demand dynamic gene expression regulation. Nat. Commun. 2019, 10, 4481. [CrossRef] [PubMed]

104. Ng, L.Y.; Ma, H.T.; Liu, J.C.Y.; Huang, X.; Lee, N.; Poon, R.Y.C. Conditional gene inactivation by combining tetracycline-mediated transcriptional repression and auxin-inducible degron-mediated degradation. Cell Cycle 2019, 18, 238-248. [CrossRef] [PubMed]

105. Gao, H.; Sun, X.; Rao, Y. PROTAC Technology: Opportunities and Challenges. ACS Med. Chem. Lett. 2020, 11, 237-240. [CrossRef] [PubMed]

106. Alabi, S.B.; Crews, C.M. Major advances in targeted protein degradation: PROTACs, LYTACs, and MADTACs. J. Biol. Chem. 2021, 296, 100647. [CrossRef]

107. Takahashi, D.; Arimoto, H. Selective autophagy as the basis of autophagy-based degraders. Cell Chem. Biol. 2021, $28,1061-1071$. [CrossRef]

108. Kaiho-Soma, A.; Akizuki, Y.; Igarashi, K.; Endo, A.; Shoda, T.; Kawase, Y.; Demizu, Y.; Naito, M.; Saeki, Y.; Tanaka, K.; et al. TRIP12 promotes small-molecule-induced degradation through K29/K48-branched ubiquitin chains. Mol. Cell 2021, 81, 1411-1424.e7. [CrossRef]

109. Rafiq, S.; Hackett, C.S.; Brentjens, R.J. Engineering strategies to overcome the current roadblocks in CAR T cell therapy. Nat. Rev. Clin. Oncol. 2020, 17, 147-167. [CrossRef] [PubMed] 